Notre Dame Law Review

Volume 83 | Issue 5

Article 1

$7-1-2008$

\title{
The Original Meaning of an Omission: The Tenth Amendment, Popular Sovereignty, and Expressly Delegated Power
}

Kurt T.Lash

Follow this and additional works at: http://scholarship.law.nd.edu/ndlr

\section{Recommended Citation}

Kurt T. Lash, The Original Meaning of an Omission: The Tenth Amendment, Popular Sovereignty, and Expressly Delegated Power, 83 Notre Dame L. Rev. 1889 (2008).

Available at: http://scholarship.law.nd.edu/ndlr/vol83/iss5/1 


\title{
ARTICLES
}

\section{THE ORIGINAL MEANING OF AN OMISSION: THE TENTH AMENDMENT, POPULAR SOVEREIGNTY, AND "EXPRESSLY" DELEGATED POWER}

\author{
Kurt T. Lash*
}

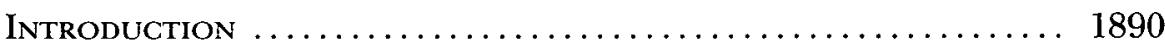

I. The Historical Background of the Tenth

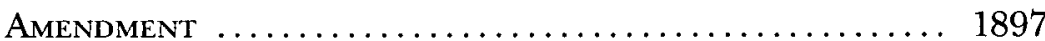

A. Methodology............................... 1897

B. The Traditional Story ........................... 1899

C. Article II of the Articles of Confederation................ 1902

D. The Federalist Response.......................... 1905

E. The State Conventions........................ 1906

F. Sovereignty and the Construction of Delegated Power ....... 1908

G. The Other Meaning of Expressly Delegated Powers ........ 1911

H. A Preexistent Principle......................... 1913

II. The Framing and Original Understanding of the Tenth AMEndment ............................... 1915

A. The State Convention Declarations and Proposed Amendments ................................ 1915

B. The Virginia Ratifying Convention ................ 1918

(C) 2008 Kurt T. Lash. Individuals and nonprofit institutions may reproduce and distribute copies of this Article in any format, at or below cost, for educational purposes, so long as each copy identifies the author, provides a citation to the Notre Dame Law Review, and includes this provision and copyright notice.

* Professor and W. Joseph Ford Fellow, Loyola Law School (Los Angeles). J.D., Yale Law School, 1992. The author thanks Larry Solum, Gary Rowe, Clark Lombardi, Nelson Lund, and the participants at the University of Washington Law School Faculty Workshop Series for their comments and suggestions on an early version of this Article. Special thanks to Chris Fritz for his help and advice on the vexing question of sovereignty in the early republic. 
C. Summary of the State Conventions ................ 1919

D. Drafting the Tenth Amendment................ 1920

E. Popular Sovereignty and the Tenth Amendment ......... 1922

III. Post-Submission Commentary................. 1926

A. The Bank Controversy.................... 1927

B. The Alien and Sedition Acts Controversy .............. 1935

C. The Nationalism of John Marshall............... 1940

1. Popular Sovereignty and McCulloch ........... 1941

2. After Marshall ...................... 1946

D. James Madison's Middle Ground .................. 1951

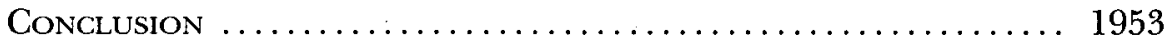

\section{INTRODUCTION}

Courts and the legal academy both generally agree that early efforts to limit the federal government to only "expressly" delegated powers were decisively rebuffed by Chief Justice John Marshall in McCulloch $v$. Maryland. ${ }^{1}$ In McCulloch, the State of Maryland argued that because chartering a bank was not within any of Congress' expressly enumerated powers, the matter was therefore left to state control under the Tenth Amendment. ${ }^{2}$ In response, Chief Justice Marshall argued that the very language of the Tenth Amendment refuted Maryland's claim:

Among the enumerated powers, we do not find that of establishing a bank or creating a corporation. But there is no phrase in the instrument which, like the articles of confederation, excludes incidental or implied powers; and which requires that every thing granted shall be expressly and minutely described. Even the 10th amendment, which was framed for the purpose of quieting the excessive jealousies which had been excited, omits the word "expressly," and declares only that the powers "not delegated to the United States, nor prohibited to the States, are reserved to the States or to the people;" thus leaving the question, whether the particular power which may become the subject of contest has been

117 U.S. (4 Wheat.) 316 (1819). There are a number of excellent monographs devoted to McCulloch. Two of the most recent include Mark R. KILlEnBECK, M'Culloch v. Maryland (2006), and Richard E. Ellis, Aggressive Nationalism (2007). Probably the best (and most influential) general treatment of the Marshall Court is G. Edward White, The Marshall Court and Cultural Change (1988).

2 According to Maryland counsel Walter Jones, "[The Constitution] is a compact between the States, and all powers which are not expressly relinquished by it, are reserved to the States." McCulloch, 17 U.S. (4 Wheat.) at 363. 
delegated to the one government, or prohibited to the other, to depend on a fair construction of the whole instrument. ${ }^{3}$

According to Marshall, the fact that the Framers of the Tenth Amendment departed from the language of the Articles of Confederation and omitted the term "expressly" suggested that they intended for Congress to have significant implied as well as expressly delegated powers. As Marshall's colleague, Justice Joseph Story, wrote in his famous Commentaries on the Constitution, all attempts to read the Tenth Amendment as calling for a strict construction "are neither more nor less than attempts to foist into the text the word "expressly." "4

Marshall's opinion in McCulloch is one of the most famous in the history of the United States Supreme Court. ${ }^{5}$ Contemporary scholars frequently cite Marshall's argument regarding the omitted word "expressly" in support of broad interpretations of federal power. ${ }^{6}$ Even those Supreme Court Justices most committed to reinvigorating federalist limits on congressional authority appear to accept the legitimacy of Marshall's "omitted text" analysis of the Tenth Amendment. ${ }^{7}$

3 Id. at 406.

42 Joseph Story, Commentaries on the Constitution of the United States $\S 1908$, at 653 (photo. reprint 1994) (Melville M. Bigelow ed., Boston, Little, Brown \& Co. 5th ed. 1891).

5 See, e.g., 4 Albert J. Beveridge, The life of John Marshall 282 (1919) ("If [Marshall's] fame rested solely on this one effort, it would be secure.").

6 See, e.g., 3 William Winslow Crosskey \& William Jeffrey Jr., Politics and the Constitution in the History of the United States 36 (1980); Calvin H. Johnson, Righteous Anger at the Wicked States 120 (2005) [hereinafter Johnson, RightEOUS ANGer]; Calvin H. Johnson, The Dubious Enumerated Power Doctrine, 22 Const. Comment. 25, 44 (2005); Robert J. Kaczorowski, Popular Constitutionalism Versus Justice in Plainclothes: Reflections from History, 73 FORDHAM L. Rev. 1415, 1423-24 (2005); William E. Leuchtenburg, The Tenth Amendment over Two Centuries: More Than a Truism, in The Tenth Amendment and State Sovereignty 41, 45-46 (Mark E. Killenbeck ed., 2002); John F. Manning, The Eleventh Amendment and the Reading of Precise Constitutional Texts, 113 Yale L.J. 1663, 1748 n.323 (2004); Paul E. McGreal, Unconstitutional Politics, 76 Notre Dame L. Rev. 519, 567 (2001); Ralph A. Rossum, The Irony of Constitutional Democracy: Federalism, the Supreme Court, and the Seventeenth Amendment, 36 SAN DiEco L. Rev. 671, 722-23 (1999); see also Printz v. United States, 521 U.S. 898, 939 n.1 (1997) (Stevens, J., dissenting) (citing the omission of "expressly" and Marshall's argument in $M c$ Culloch); U.S. Term Limits, Inc. v. Thornton, 514 U.S. 779, 853 (1995) (Thomas, J., dissenting) (same); Jack N. Rakove, The Second Amendment: The Highest Stage of Originalism, 76 CHI.-KenT L. Rev. 103, $125 \mathrm{n} .51$ (2000) (using the assumed significance of the omitted term "expressly" for the Tenth Amendment to make analogous claims for the significance of omitting any reference to "standing armies" in the Second Amendment).

7 See U.S. Term Limits, 514 U.S. at 853 (Thomas, J., dissenting); see also Mark R. Killenbeck, Pursuing the Creat Experiment: Reserved Powers in a Post-Ratification, Compound Republic, 1999 SuP. CT. Rev. 81, 111-13 (“For example, Justice O'Connor's 
In fact, Marshall's point in McCulloch about the missing word "expressly" is probably one of the least controversial claims about the original understanding of Tenth Amendment.

It is also almost certainly wrong. Even before the addition of the Bill of Rights, advocates of the new Constitution insisted that Congress had only expressly enumerated powers. According to James Madison, the addition of the Ninth and Tenth Amendments merely confirmed the preexisting principle of expressly delegated power. ${ }^{8}$ During the early decades of the Constitution, judges and commentators regularly inserted into their description of the Tenth Amendment the very word John Marshall insisted had been intentionally left out. These statements took place during and immediately after ratification and were voiced by a broad range of figures directly involved in the effort to ratify the Constitution.

The most vocal proponents of this view were Federalist supporters of the Constitution. For example, throughout the ratification debates Federalist proponents of the Constitution insisted that Congress had only expressly delegated powers. In the New York ratifying convention, Alexander Hamilton declared that "whatever is not expressly given to the federal head, is reserved to the members." 9 In the South Carolina debates, Federalist Charles Pinckney insisted that "no powers could be executed or assumed [by the federal government], but such as were expressly delegated." 10 In a speech delivered to the House of Representatives while the Bill of Rights remained pending in the states, James Madison reminded the assembly that the proponents of the Constitution had assured the states that "the general government could not exceed the expressly delegated powers." 11 Speaking shortly

opinions evidence an extraordinary fixation on a Tenth Amendment within which the only apparent value is its affirmation of the primacy of state government."); David M. Sprick, Ex Abundanti Cautela (Out of an Abundance of Caution): A Historical Analysis of the Tenth Amendment and the Continuing Dilemma over "Federal" Power, 27 CAP. U. L. Rev. 529, 537-38 (1999) (noting Justice Story's rejection of the characterization that the Tenth Amendment acted as an abridgment of any constitutionally granted powers).

8 See infra note 176 and accompanying text.

92 The Debates in the Several. State Conventions on the Adoption of the Federal Constitution 362 (Jonathan Elliot ed., Phila., J.B. Lippincott Co. 2d ed. 1891) [hereinafter Elliot's DEBATEs] (reporting the remarks of Alexander Hamilton to the New York ratifying convention on June 28, 1788). Hamilton would take a far broader view of federal power following the adoption of the Constitution. See infra notes 158-59 and accompanying text.

104 Elliot's Debates, supra note 9, at 253-63 (reporting a speech by Charles Pinckney before the South Carolina House of Representatives on January 16, 1788).

11 Congressional Proceedings, Fed. Gazette (Phila., Pa.), Feb. 12, 1791, at 2 [hereinafter Congressional Proceedings, Fed. Gazetre]. 
after the adoption of the Bill of Rights, Madison again declared that " $[w]$ hen the people have formed a Constitution, they retain those rights which they have not expressly delegated."12 According to Representative John Page, a member of the First Congress that drafted and debated the Bill of Rights, the combined effect of the Ninth and Tenth Amendments rendered the Tenth as if it had in fact included the term "expressly."13 Finally, in one of the most famous decisions of the Supreme Court's first decade, Justice Samuel Chase declared that "the several State Legislatures retain all the powers of legislation, delegated to them by the State Constitutions; which are not EXPREsSLY taken away by the Constitution of the United States." 14 These are just a few examples that can be found easily in the historical record. There are many others. They arise in every major period of American constitutional law, from the Founding, ${ }^{15}$ to the Reconstruction era, ${ }^{16}$ to the Lochner era, ${ }^{17}$ and right up to the modern Supreme Court. ${ }^{18}$

We are confronted then with a puzzle. Despite Chief Justice Marshall's seemingly unanswerable argument regarding the omission of the term "expressly" from the Tenth Amendment, there exists a longstanding tradition, from the Founding to the modern Supreme Court, whereby the principle underlying the Tenth Amendment is presented as containing the very word its Framers rejected.

This Article contends that this tradition, and not Marshall's argument in McCulloch, most accurately reflects the original understanding of federal power and the Tenth Amendment. In addition to a remarkably copious historical record, support for this position can be found in two significant pieces of historical evidence that until now have gone completely unnoticed. The first is a major speech by James Madison in which he declared that the Bill of Rights, including the

124 Annals of Cong. 934 (1794) (statement of Rep. Madison).

13 John Page, Address to the Freeholders of Gloucester County 28 (Richmond, John Dixon 1799) ("I say, considering these things, how could it be possible to suppose, that these two amendments [the Ninth and Tenth] taken together, were not sufficient to justify every citizen in saying, that the powers not delegated to the United States by the constitution, nor prohibited by it to the states, are reserved to the states respectively, or to the people, as fully and completely; as if the word expressly had been inserted?").

14 Calder v. Bull, 3 U.S. (3 Dall.) 386, 387 (1798).

15 See infra notes $66-68$ and accompanying text.

16 See infra note 260 and accompanying text.

17 See infra note 244 and accompanying text.

18 See infra note 279 and accompanying text; see also Griswold v. Connecticut, 381 U.S. 479, 490 n.5 (1965) (Goldberg, J., concurring) ("The Tenth Amendment similarly made clear that the States and the people retained all those powers not expressly delegated to the Federal Government."). 
Tenth Amendment, delivered on a promise to the state conventions that the federal government would have only expressly delegated power. Although the speech is well known, Madison's declaration is not, for it is reported in a version of Madison's speech consistently passed over by historians. ${ }^{19}$ Secondly, although the Framers of the Tenth Amendment rejected the term "expressly," they added the phrase "reserved to the States respectively, or to the people"20_a declaration of nondelegated sovereign power. At the time, the concept of popular sovereignty was understood to embrace the attendant principle that all power delegated away by the people would be strictly construed. This explains why the phrase "or to the people" was suggested by the same man who wanted to add the term "expressly"-a fact rather remarkably omitted from all prior accounts of the Tenth Amendment. Adding a declaration of the retained sovereign powers of the people in the several states by definition limited the federal government to only expressly delegated powers. Properly understood, "expressly delegated power" included the power to adopt those means incident to advancing the expressly enumerated end, but required these implied means to be clearly or directly related to the express grant of power. It required, in other words, that delegated power be strictly construed.

In addition to presenting newly uncovered historical evidence regarding the original meaning of the Tenth Amendment, this Article challenges a number of commonly held assumptions regarding the early history of the Constitution. In particular, it establishes that it was the advocates of the proposed Constitution who consistently declared that federal power would be narrowly construed. This runs counter to the frequent narrative which portrays strict constructionists as Antifederalist dissenters and their descendents. ${ }^{21}$ It also suggests that, despite conventional wisdom which suggests that the Constitution contains no rules regarding the proper method of its interpretation, those who debated and ratified the document believed the text did in fact contain both express and implied rules of construction, particularly in regard to delegated federal power. Finally, this account calls into question the generally unchallenged reasoning of John Marshall's opinion in McCulloch. It appears that the original meaning of the

19 See infra notes 162-69 and accompanying text.

20 U.S. Const. amend. $\mathrm{X}$ (emphasis added).

21 See Saul Cornell, The Other Founders 187-94 (1999) (defining antifederalism at various moments throughout the evolving tradition of dissenting public discourse); JohnSON, Righteous ANGer, supra note 6, at 175. 
omitted term "expressly" is quite different than Chief Justice Marshall would have us believe.

Following a brief introduction to the methodology employed in this Article, Part I explores the historical background to the framing of the Tenth Amendment and the Bill of Rights. Reacting against the constricted scope of congressional power under the Articles of Confederation, the members of the Philadelphia Convention presented a Constitution with an expansive degree of federal authority, including the power to enact all laws necessary and proper to advance enumerated responsibilities. ${ }^{22}$ When the proposed Constitution was submitted to the states, however, concerns immediately arose that the Constitution delegated unchecked authority into the hands of the federal government and imperiled the independent and sovereign existence of the people in the several states. In response, advocates of the Constitution assured the ratifiers in the state conventions that Congress would have only expressly enumerated powers. This was not a denial of implied federal power, but an assurance that those implied powers would be limited to those necessarily incident to the express grant of authority. Strict construction of delegated power was an inherent aspect of popular sovereignty, a political theory which assumed that power delegated by a sovereign should be narrowly construed.

Part II focuses on the framing and original understanding of the Tenth Amendment. Along with their notice of ratification, most of the state conventions either proposed amendments which would restrict the new Congress to expressly enumerated powers or submitted "declarations" indicating their understanding that this principle already informed the Constitution. Delivering on a promise made to the Virginia convention, James Madison proposed a Bill of Rights, including early drafts of the Ninth and Tenth Amendments. Unlike Article II of the Articles of Confederation, Madison's proposed Tenth Amendment omitted the term "expressly" and he successfully turned aside efforts to add that term to the final language of the Amendment. Although Madison's speeches and letters indicate that he feared adding the term "expressly" might erroneously suggest that Congress had no implied powers whatsoever, he nevertheless agreed with the idea that the Constitution granted only "expressly delegated" (and thus narrowly construed) authority. Madison thereby joined the majority of Congress in voting to add the language of popular sovereignty to both the Ninth and Tenth Amendments, thus ensuring that federal power would be understood as having been delegated to the

22 See U.S. Const. art. I, § 8, cl. 18. 
government by the people, thereby calling for a limited construction of the grant.

Part III explores the post-adoption understanding of the Tenth Amendment and the emerging struggle between nationalists like Alexander Hamilton and John Marshall and men like James Madison and St. George Tucker who insisted on standing by the promises made to the state ratifying conventions. The divide emerged even before the adoption of the Bill of Rights with the debate over the First Bank of the United States. Taking a far broader view of federal power than he had during the ratification debates, Hamilton now argued that the Bank fell within the necessary and proper powers of Congress. Madison, on the other hand, insisted that the Bank violated the principle of expressly delegated power-a principle properly relied upon by the ratifiers in the state conventions. Before the end of first decade of the Constitution, the struggle over the proper interpretation of federal power reached a climax in the controversy surrounding the Alien and Sedition Acts. Relying on arguments startlingly similar to those upon which Marshall would rely in McCulloch, defenders of the Sedition Act pointed to the omission of the term "expressly" from the Tenth Amendment as evidence of broadly delegated federal power. In response, men from the founding generation like John Page and St. George Tucker insisted that the adoption of the Ninth and Tenth Amendments established the principle of expressly delegated power, despite the omission of the word. Although the Federalists' nationalist approach fell out of favor with the dramatic victory of the Republicans in the election of 1800 , Marshall revived the same theory two decades later in decisions like McCulloch and Gibbons v. Ogden. ${ }^{23}$ Marshall's broad interpretation of federal power (and narrow view of the Tenth Amendment) faded upon his death, only to be restored at the time of the New Deal.

This Article concludes with an analysis of James Madison's "middle way." Rejecting both the radical states' rights position and the consolidating nationalist position of men like Marshall and Hamilton, Madison advocated a limited construction of federal power-one that he believed had been promised to the parties that ratified the Constitution. Even taking into consideration the adoption of the Fourteenth Amendment, an originalist reading of the Tenth Amendment which tracks Madison's reading of the clause would place the contemporary Court's federalism jurisprudence on firmer ground, both in terms of the Constitution's text and historical understanding.

2322 U.S. (9 Wheat.) 1 (1824). 


\section{The Historical. Background of the Tenth Amendment}

\section{A. Methodology}

This Article employs the interpretive methodology of originalism. The goal is to identify-to the extent possible-the likely original meaning of the Tenth Amendment. Unlike earlier iterations of originalism which sought the original intent of the Framers, most originalists today seek the original understanding of those who debated and ratified the constitutional text. ${ }^{24}$ Accordingly, although evidence of the private intent of the Framers is relevant to understanding the likely public meaning of the text, the focus here is on determining the likely meaning of the Amendment as it was received by its ratifiers - those with the sovereign authority to establish the text as fundamental law. ${ }^{25}$

This is not a new idea. The man primarily responsible for the Constitution and the Bill of Rights, James Madison, insisted that the document be interpreted according to the understanding of its ratifiers. According to Madison:

[W] hatever veneration might be entertained for the body of men who formed our Constitution, the sense of that body could never be regarded as the oracular guide in expounding the Constitution. As the instrument came from them it was nothing more than the draft of a plan, nothing but a dead letter, until life and validity were breathed into it by the voice of the people, speaking through the several State Conventions. If we were to look, therefore, for the meaning of the instrument beyond the face of the instrument, we must look for it, not in the General Convention, which proposed, but in the State Conventions, which accepted and ratified the Constitution. ${ }^{26}$

24 See Randy E. Barnett, An Originalism for Nonoriginalists, 45 Loy. L. REv. 611, 620 (1999).

25 Although all contemporary originalists seek to identify the original understanding of the ratifiers, the effort is particularly important for popular sovereignty-based originalism, a normative theory of constitutional interpretation which maintains that we ought to follow the meaning of the text as it was understood by the people who added it to the Constitution. See Keith E. Whitrington, Construtional Interpretation 110-59 (1999); see also Kurt T. Lash, Originalism, Popular Sovereignty and Reverse Stare Decisis, 93 VA. L. Rev. 1437, 1444-48 (2007) (arguing that because the Constitution and its amendments are the product of an "independent and supermajoritarian process by which certain legal norms can be entrenched, or immunized, from the ordinary political process," the Court ought to invalidate "[a]ny legislative action that diverges from this higher law").

265 AnNals of Cong. 776 (1796) (statement of Rep. Madison). 
Identifying the original meaning does not necessarily establish contemporary meaning. Not only might the original scope of an amendment have been significantly affected by later amendments, any one of a number of normative theories maintain that original understanding need not (or ought not) be determinative for contemporary interpretations of the Constitution. ${ }^{27}$ Most theories of contemporary constitutional interpretation, however, consider original understanding to be at least relevant to the modern understanding of the Constitution. ${ }^{28}$

Finally, readers should be aware that the available historical record regarding the original Bill of Rights, particularly in regard to the Ninth and Tenth Amendments, has dramatically increased over the past few years. Much of this evidence calls into question a number of longstanding assumptions regarding the role of federalism in the original drafting and ratification of the Constitution and the Bill of Rights. ${ }^{29}$ This Article builds upon and extends this newly expanded historical record.

27 See Bruce Ackerman, The Living Constitution, 120 HaRv. L. Rev. 1737, 1804-05 (2007).

28 Once associated with the political goals of the right, the originalist enterprise has come to be embraced by a wide spectrum of constitutional theorists. Some of the most influential liberal constitutional works of the 1980s and 1990s employed sophisticated originalist analysis. See 1 Bruce Ackerman, We the People: Foundations 131-229 (1991); 2 Bruce Ackerman, We the People: Transformations 32-95 (1998); Akhil Refd Amar, The Bill of Rights (1998). Recent originalist work by libertarian, liberal, and federalist scholars have all shed important light on the original understanding of the Constitution. See Randy E. Barnett, Restoring the Lost Constitution 89-117 (2003); Larry D. Kramer, The People Themselves 9-34 (2004); Jack M. Balkin, Abortion and Original Meaning, 24 Const. Comment. 291 (2007).

29 In a series of recent articles, I have presented a significant body of previously unknown or unrecognized evidence regarding the original understanding and traditional application of the Ninth and Tenth Amendments. See Kurt T. Lash, The Lost Jurisprudence of the Ninth Amendment, 83 TEx. L. REv. 597 (2005) [hereinafter Lash, Lost Jurisprudence]; Kurt T. Lash, The Lost Original Meaning of the Ninth Amendment, 83 TEx. L. REv. 331 (2004) [hereinafter Lash, Original Meaning]; Kurt T. Lash, On Federalism, Freedom, and the Founders' View of Retained Rights: A Reply to Randy Barnett, 60 STAN. L. Rev. 969 (2008); Kurt T. Lash, A Textual-Historical Theory of the Ninth Amendment, 60 Stan. L. Rev. 895 (2008) [hereinafter Lash, Textual-Historical Theory]. For a counterreading of some of this evidence, see Randy E. Barnett, Kurt Lash's Majoritarian Difficulty: A Response to A Textual-Historical Theory of the Ninth Amendment, 60 STAN. L. Rev. 937 (2008); Randy E. Barnett, The Ninth Amendment: It Means What It Says, 85 TEx. L. Rev. 1, 4-5, 21-76 (2006). 


\section{B. The Traditional Story}

Contemporary accounts of the Tenth Amendment generally focus on the tug-of-war between the Antifederalists who wanted to restrict the scope of federal power, and the Federalists, who wanted to avoid repeating the problems with the Articles of Confederation. ${ }^{30}$ Under Article II of the Articles, the states retained all power, jurisdiction, and rights not expressly delegated to the federal government. ${ }^{31}$ The Constitution proposed by the Philadelphia Convention, however, had no such reservation clause. The omission raised immediate concerns among both the enemies and the tentative friends of the Constitution. Antifederalists opposed the very idea of a strong centralized government. ${ }^{32}$ But even those otherwise disposed to be in favor of a new federal government nevertheless balked at the lack of any provision explicitly limiting the scope of its power. ${ }^{33}$

In response, Federalists insisted that Congress could never claim any powers beyond those listed in the Constitution. Adding particular restrictions was therefore unnecessary. ${ }^{34}$ As far as the old Article II

30 There are numerous excellent (if incomplete) accounts of the history behind the adoption of the Tenth Amendment. One of the best is Charles A. Lofgren, The Origins of the Tenth Amendment: History, Sovereignty, and the Problem of Constitutional Intention, in Constitutional Government in America 331 (Ronald K.L. Collins ed., 1980). Others include Thomas B. MaAffee et al., Powers Reserved for the People and the States 39-44 (2006); Jack N. Rakove, American Federalism: Was There an Original Understanding?, in The TeNTH Amendment and State Sovereignty, supra note 6, at 107. For a general account of the adoption of the Bill of Rights, see LEONARD W. LeVY, ORIGins of THE Bill of Rights (1999).

31 See Articles of Confederation art. II (U.S. 1781) ("Each state retains ... every power, jurisdiction and right, which is not by this confederation expressly delegated to the United States, in Congress assembled."). Article II did not completely hamstring the government. Congress managed, for example, to find the authority to charter a national bank under the Articles of Confederation, despite the lack of a text expressly granting such authority. See KiLLENBECK, supra note 1, at 11.

32 See, e.g., Essays of Brutus No. 1, N.Y.J., Oct. 18, 1787, at 2, reprinted in 2 THE Complete AnTI-Federalist 363, 367 (Herbert J. Storing \& Murray Dry eds., 1981) (arguing that the proposed central government would exercise its commerce power "to annihilate all the state governments, and reduce this country to one single government"); Essays of an Old Whig (VI), INDEP. GAZetTeER (Phila., Pa.), Nov. 24, 1787, at 2, reprinted in 3 THE COMPLETE ANTI-FEDERALIST, supra, at 38, 43 (arguing that granting Congress the power to tax would "annihilate the individual states").

33 See infra notes 85-86 and accompanying text (discussing the concerns of Edmund Randolph).

34 Not only was a bill unnecessary given the doctrine of enumerated powers, but moreover adding a list of enumerated rights, Federalists argued, might raise a dangerous presumption of otherwise unlimited federal power. See THE Federalist No. 84, at 519 (Alexander Hamilton) (Clinton Rossiter ed., 1961) ("I go further and affirm that bills of rights, in the sense and to the extent in which they are contended for, are not 
was concerned, Federalists pointed out that this provision had placed the national government in the untenable position of either doing nothing, or appearing to intentionally flout the requirement that all laws find express authorization in the Articles of Confederation. As James Madison argued in Federalist No. 44:

Had the convention [followed the] method of adopting the second article of Confederation, it is evident that the new Congress would be continually exposed, as their predecessors have been, to the alternative of construing the term "expressly" with so much rigor as to disarm the government of all real authority whatever, or with so much latitude as to destroy altogether the force of the restriction. ${ }^{35}$

As Alexander Hamilton explained, if the Framers of the Constitution had added a provision like Article II, then Congress would have been "reduced to the dilemma either of supposing that deficiency, preposterous as it may seem, or of contravening or explaining away a provision, which has been of late a repeated theme of the eulogies of those who oppose the new Constitution."36

Even if Madison and Hamilton were correct about the need to avoid repeating the language of Article II, the fact remained that the Constitution as originally proposed lacked any provision expressly limiting the scope of federal power-an omission especially disconcerting for those who also questioned the omission of a Bill of Rights. In order to ensure ratification and head off a second constitutional convention, Madison and the Federalists promised that, should the proposed Constitution be ratified, adding a Bill of Rights would be one of the first tasks of the new Congress. ${ }^{37}$ The promise proved sufficient to garner the requisite votes for ratification and Madison kept his word by submitting a list of proposed amendments to the new House of Representatives. ${ }^{38}$ One of these was a draft of what would become our Tenth Amendment-a provision clearly mirroring Article II of the Articles of Confederation, though lacking the restrictive term

only unnecessary in the proposed Constitution but would even be dangerous. . . For why declare that things shall not be done which there is no power to do?"); see also The Complete Bill of Rights 647-48 (Neil H. Cogan ed., 1997) (reporting the remarks of Mr. Wilson suggesting that a bill of rights was "unnecessary" and "dangerous").

35 The Federalist No. 44 (James Madison), supra note 34, at 284; see also Stanley Elkins \& Eric McKitrick, The Age of Federalism 231 (1993) (discussing the role of Federalist No. 44 in the later controversy over the Bank of the United States).

36 The Federalist No. 21 (Alexander Hamilton), supra note 34, at 139.

37 See Levy, supra note 30 , at 30-31.

38 See id. at $32-35$. 
"expressly" in describing the powers delegated to Congress: "[ $t]$ he powers not delegated by the Constitution, nor prohibited by it to the States, are reserved to the States respectively." 39 When the House debated the proper drafting of the Tenth Amendment, some members attempted to restore the language of Article II. In an exchange widely cited in support of John Marshall's reading of the Tenth Amendment, James Madison turns aside Thomas Tucker's attempt to add the term "expressly" to the Amendment:

Mr. TUCKER proposed to amend the proposition, by prefixing to it "all powers being derived from the people." He thought this a better place to make this assertion than the introductory clause of the Constitution, where a similar sentiment was proposed by the committee. He extended his motion also, to add the word "expressly," so as to read "the powers not expressly delegated by this Constitution."

Mr. Madison objected to this amendment, because it was impossible to confine a Government to the exercise of express powers; there must necessarily be admitted powers by implication, unless the constitution descended to recount every minutiae. He remembered the word "expressly" had been moved in the convention of Virginia, by the opponents to the ratification, and, after full and fair discussion, was given up by them, and the system allowed to retain its present form.

Mr. TUCKER did not view the word "expressly" in the same light with the gentleman who opposed him; he thought every power to be expressly given that could be clearly comprehended within any accurate definition of the general power.

Mr. TUCKER's motion being negatived,

Mr. Carroll proposed to add to the end of the proposition, "or to the people;" this was agreed to. ${ }^{40}$

391 AnNals of Cong. 761 (Joseph Gales ed., 1834).

40 Id. (emphasis added). On August 21, there was a second unsuccessful attempt to restore the term "expressly":

The ninth proposition Mr. GERRY proposed to amend by inserting the word "expressly," so as to read "the powers not expressly delegated by the Constitution, nor prohibited to the States, are reserved to the States respectively, or to the people." As he thought this an amendment of great importance, he requested the yeas and nays might be taken. He was supported in this by one-fifth of the members present; whereupon they were taken, and were as follows:

Yeas-Messrs. Burke, Coles, Floyd, Gerry, Grout, Hathorn, Jackson, Livermore, Page, Parker, Partridge, Van Rensselaer, Smith, (of South Carolina,) Stone, Sumter, Thatcher, and Tucker-17. 
In the end, the House on two separate occasions rejected an attempt to add the restrictive term "expressly" to the Tenth Amendment. ${ }^{41}$ Whatever one makes of this history, one cannot say the omission was inadvertent. But what can one make of it? Despite such a clear and considered rejection, we know that there are numerous examples of Founders, including Hamilton and Madison, embracing the very term they so vigorously fought to exclude from the Constitution. Getting a handle on this mystery requires a closer look at both the history of Article II of the Articles of Confederation and the debates surrounding the ratification of the Constitution. ${ }^{42}$

\section{Article II of the Articles of Confederation}

After formally announcing the break with England, the newly "free and independent States" 43 ultimately organized themselves into a loosely formed confederacy under the Articles of Confederation. ${ }^{44}$ The original draft of what would become Article II contained a general reservation of nondelegated power to the states: "[e]ach Colony shall retain and enjoy as much of its present Laws, Rights and Customs, as it may think fit, and reserves to itself the sole and exclusive Regulation and Government of its internal police, in all matters that shall not interfere with the Articles of this Confederation." 45

Thomas Burke of North Carolina objected that this proposed language insufficiently protected the sovereign states. As he explained in a letter to North Carolina Governor Richard Caswell:

Nays-Messrs. Ames, Benson, Boudinot, Brown, Cadwalader, Carroll, Clymer, Fitzsimons, Foster, Gale, Gilman, Goodhue, Hartley, Heister, Lawrence, Lee, Madison, Moore, Muhlenburg, Schureman, Scott, Sedgwick, Seney, Sherman, Sylvester, Sinnickson, Smith, (of Maryland,) Sturges, Trumbull, Vining, Wadsworth, and Wynkoop-32.

Id. at 767-68.

41 The additional attempt was made on August 21. See id.

42 An easy, if cynical, explanation would be that the advocates of the Constitution engaged in dissembling. The historical record, however, reveals how these seemingly conflicting statements can be reconciled. See infra Part II.D. Even if one accepts the dissembling explanation, however, the ratifiers were entitled to treat Federalist explanations of the Constitution as made in good faith. For an example of the "dissembling" reading of the statements made by the Federalists during the ratification debates, see Johnson, Righteous Anger, supra note 6, at 174-75.

43 The Declaration of IndePendence para. 31 (U.S. 1776).

44 See Articles of Confederation art. II (U.S. 1781). Although the Articles were drafted and adopted by the Second Continental Congress in 1777, they were not formally ratified until 1781 .

455 Journals of the Continental Congress 1774-1789, at 547 (Worthington Chauncey Ford ed., 1906). 
[The original draft of Article II] expressed only a reservation of the power of regulating internal police, and consequently resigned every other power. It appeared to me that this was not what the States expected, and, I thought, it left it in the power of the future Congress or General Council to explain away every right belonging to the States, and to make their own power as unlimited as they please. I proposed, therefore, an amendment, which held up the principle, that all sovereign Power was in the States separately, and that particular acts of it, which should be expressly enumerated, would be exercised in conjunction, and not otherwise; but that in all things else each State would Exercise all the rights and powers of sovereignty, uncontrolled. ... [I]n the End however the question was carried for my proposition, Eleven ayes, one no, and one divided. ${ }^{46}$

Burke sought to reverse the presumption of the originally proposed language from implying that "all power not expressly retained is granted," to "all power not expressly granted is retained." As amended per Burke's suggestion, here is the final version of Article II: "[e]ach State retains its sovereignty, freedom, and independence, and every power, jurisdiction, and right, which is not by this confederation, expressly delegated to the United States, in Congress assembled." 47

Article II's demand that all federal acts have express authorization in the Articles could be construed in different ways. For example, it could mean that federal acts needed to be expressly authorized or clearly inferable from an express authorization. A narrower construction of the text, however, would seem to deny Congress the authority to take any action not specifically mentioned in the text of the Articles. For example, opponents of the Bank of North America relied upon a strict reading of Article II in arguing that Congress had exceeded its "expressly delegated". powers. ${ }^{48}$ As Alexander Hamilton complained in The Federalist, a strict reading of Article II forced Congress to choose between utter immobility or blatant disregard of an express restriction on the delegated powers of Congress. ${ }^{49}$ Not sur-

46 Letter from Thomas Burke, Delegate, to Richard Caswell, Governor (Apr, 29, 1777), in 6 Letters of Delegates to Congress 671, 672 (Paul H. Smith et al. eds., 1980).

47 Articles of Confederation art. II (U.S. 1781).

48 See James Wilson, Considerations on the Bank of North America (1785), reprinted in 1 Collected WORKS OF JAMES Wilson 60, 65 (Kermit L. Hall \& Mark David Hall eds., Liberty Fund 2007). For a defense of Congress' power to create the Bank of North America, despite the restrictions of the Articles of Confederation, see id. at $60-79$.

49 According to Hamilton in Federalist No. 21: 
prisingly, when it came time to draft a new constitution, the delegates of the Philadelphia Convention declined to add anything like the problematic Article II.

The omission of a provision like Article II, however, left the proposed Constitution without any express limitation on the construction of federal authority. Unlike most state constitutions, the Federal Constitution did not contain a Bill of Rights. Instead, provisions like the Necessary and Proper Clause appeared to affirmatively authorize expansive interpretations of federal power. ${ }^{50}$ According to the Antifederalist writer Centinel, "[T]he omission of such a declaration [as Article II] now, when such great devolutions of power are proposed, manifests the design of reducing the several States to shadows."51 Antifederalist broadsides repeatedly raised concerns about unlimited federal power and the potential "consolidation" of the states. ${ }^{52}$

The next most palpable defect of the existing Confederation is the total want of a SANCTION to its laws. The United States as now composed have no power to exact obedience, or punish disobedience to their resolutions, either by pecuniary mulcts, by a suspension or divestiture of privileges, or by any other constitutional means. There is no express delegation of authority to them to use force against delinquent members; and if such a right should be ascribed to the federal head, as resulting from the nature of the social compact between the States, it must be by inference and construction in the face of that part of the second article by which it is declared "that each State shall retain every power, jurisdiction, and right, not expressly delegated to the United States in Congress assembled."

The Federalist No. 21 (Alexander Hamilton), supra note 34, at 138-39. Hamilton was, of course, exaggerating in order to support his argument against keeping the Articles. Under the Articles, Congress had managed to establish the Bank of North America despite the lack of any express authorization. Although men like James Madison believed the Bank to be beyond the delegated authority of the Articles, others like James Wilson argued that the limitation to expressly delegated powers nevertheless left room for the establishment of the Bank. See WILSON, supra note 48, at $60-79$.

50 See The Federalist No. 33 (Alexander Hamilton), supra note 34, at 203 (referring to the Necessary and Proper Clause as "the sweeping clause").

51 Letters of Centinel No. 2, Mo. J. (Balt., Md.), Nov. 2, 1787, at 1, reprinted in 2 THE Complete Anti-Federalist, supra note 32, at 143, 146-47.

52 According to the Antifederalist writer Brutus:

How far the clause in the 8th section of the 1st article may operate to do away all idea of confederated states, and to effect an entire consolidation of the whole into one general government, it is impossible to say. The powers given by this article are very general and comprehensive, and it may receive a construction to justify the passing almost any law. A power to make all laws, which shall be necessary and proper, for carrying into execution, all powers vested by the constitution in the government of the United States, or any department or officer thereof, is a power very comprehensive and definite, 


\section{The Federalist Response}

The widespread criticism of the failure to include specific limits on federal power placed the Federalists on the defensive, having to explain why the proposed Constitution did not pose the danger insisted upon by its opponents. The defense of the proposed Constitution took various forms, but a theme running throughout the Federalists' apologies was that there was no need to add a clause like Article II of the Articles of Confederation: the federal government would have no more than expressly delegated powers. According to Charles Pinckney in a speech defending the proposed Constitution before the South Carolina House of Representatives in January 1788:

The distinction which has been taken between the nature of a federal and state government appeared to be conclusive-that in the former, no powers could be executed, or assumed, but such as were expressly delegated; that in the latter, the indefinite power was given to the government, except on points that were by express compact reserved to the people. ${ }^{53}$

In Massachusetts, newspapers published Roger Sherman's Observations on the New Federal Constitution, and the Alterations That Have Been Proposed as Amendments, in which he explained: "The powers vested in the federal government are particularly defined, so that each State still retains its sovereignty in what concerns its own internal government, and a right to exercise every power of a sovereign State, not expressly delegated to the government of the United States." 54

and may, for ought I know, be exercised in a such manner as entirely to abolish the state legislatures.

Essays of Brutus No. I, supra note 32, at 367; see also CoRNel., supra note 21, at 29-30 (listing consolidation as one of the main issues recurring in Antifederalist writings based on the concern that "consolidated government undermines both republicanism and liberty"); Daniel Wirls \& Stephen WiRls, The Invention of the United States Senate 136 (2004) (naming "consolidation" of the sovereign states as one of the key Antifederalist concerns during the ratification debates); Gordon S. WOOD, The Creation of the American Republic 524-32 (W.W. Norton ed., 1972) (discussing Antifederalist fears of consolidation).

534 Elliot's Debates, supra note 9, at 259-60 (reporting the speech of Charles Pinckney before the South Carolina House of Representatives on January 16, 1788). Pinckney's speech in its entirety was reprinted in South Carolina and Pennsylvania newspapers. See Legislative Proceedings, CrTy GAzETte (Charleston, S.C.), Jan. 25, 1788, at 2; Legislative Proceedings, PA. PaCket (Phila., Pa.), Feb. 21, 1788, at 2.

54 A Citizen of New Haven [Roger Sherman], Observations on the New Federal Constitution, and the Alterations That Have Been Proposed as Amendments (pts. 1 \& 2), SALEM Mercury, June 30, 1789, at 1, Salem Mercury, July 7, 1789, at 1 [hereinafter Observations, Salem Mercury]. 
In the same Massachusetts newspaper, the editors published an essay rejecting Antifederalist concerns about unlimited power. According to the editorial, "The constitution defines the powers of Congress; \& every power not expressly delegated to that body, remains in the several state legislatures." 55 In New Jersey, the local newspaper published an essay defending the proposed Constitution and declaring that "in America (thanks to the interposing providence of GoD!) the people hold all power, not by them expressly delegated to individuals, for the good of the whole." ${ }^{56}$ In Virginia, Alexander White published To the Citizens of Virginia, in which he declared that "should Congress attempt to exercise any powers which are not expressly delegated to them, their acts would be considered as void, and disregarded." 57

All of these declarations that Congress would have only expressly delegated powers came from advocates of the proposed Constitution. ${ }^{58}$ Despite conventional wisdom, it was not the ultimately unsuccessful Antifederalists who originally insisted on strict construction of expressly delegated federal power. Narrow interpretation of federal power emerged as a promise by those most interested in ratifying the Constitution.

\section{E. The State Conventions}

In the state ratifying conventions, the Federalists repeatedly insisted that the federal government would have only expressly delegated powers. In the North Carolina convention, Archibald Maclaine defended the decision to omit a Bill of Rights on the ground that

the powers of Congress are expressly defined; and the very definition of them is as valid and efficacious a check as a bill of rights could be, without the dangerous implication of a bill of rights. The powers of Congress are limited and enumerated. . . . It is as plain a thing as possibly can be, that Congress can have no power but what we expressly give them." 59

55 Editorial, Salem Mercury, Jan. 15, 1788, at 1 .

56 A Correspondent, N.J.J. (Elizabethtown, N.J.), Dec. 19, 1787, at 2.

57 Alexander White, To the Citizens of Virginia, Winchester VA. GazeTte, Feb. 29, 1788, reprinted in 8 The Documentary History of the Ratification of the ConstituTION 438, 438 (John P. Kaminski \& Gaspare J. Saladino eds., 1988).

58 For a discussion of the Federalists' use of "expressly delegated powers" in support of the proposed Constitution, see Wood, supra note 52, at 539-43. As Wood illustrates, the concept of expressly delegated power was inextricably linked to the emerging concept of popular sovereignty. See id.

594 Ellior's Debates, supra note 9, at 140-41 (reporting the remarks of Archibald Maclaine before the North Carolina convention on July 28, 1788). 
The president of the convention, Governor Samuel Johnston, agreed and insisted that "[ $\mathrm{t}]$ he Congress cannot assume any other powers than those expressly given them, without a palpable violation of the Constitution." 60

Sounding a theme that would be repeated throughout the state conventions, former member of the Philadelphia Convention and future Supreme Court Justice James Iredell stressed the link between the people's retained sovereignty and expressly delegated power:

Of what use therefore, can a bill of rights be in this Constitution, where the people expressly declare how much power they do give, and consequently retain all they do not? It is a declaration of particular powers by the people to their representatives, for particular purposes. It may be considered as a great power of attorney, under which no power can be exercised, but what is expressly given. Did any man ever hear, before, that at the end of a power of attorney it was said that the attorney should not exercise more power than was there given him? ${ }^{61}$

Although in The Federalist Alexander Hamilton had stressed the need to abandon Article II, in his arguments before the New York convention Hamilton nevertheless assured the convention that "whatever is not expressly given to the federal head, is reserved to the members. The truth of this principle must strike every intelligent mind."62 According to Hamilton, the sovereign people of the states "have already delegated their sovereignty and their powers to their several governments; and these cannot be recalled, and given to another, without an express act."63 Hamilton's statement illustrates the link between popular sovereignty and the narrow construction of expressly delegated power-a link that ultimately informed both the Ninth and Tenth Amendments.

60 Id. at 142 (reporting the statement of Samuel Johnston before the North Carolina convention on July 22,1788 ).

61 Id. at 148-49. In spite of the Federalists' best efforts, a majority of the convention remained unconvinced and voted against the proposed Constitution 184 to 84 . See id. at 250. North Carolina ultimately ratified only after Congress drafted and circulated for ratification a proposed Bill of Rights. See Chronology, 1786-1790, in 13 The Documentary History of the Ratification of the Constitution, at xl-xlii (John P. Kaminski et al. eds., 1981).

622 Elliot's Debates, supra note 9, at 362 (reporting the remarks of Alexander Hamilton to the New York ratifying convention on June 28, 1788).

63 Id. at 362-63 (emphasis added). 


\section{F. Sovereignty and the Construction of Delegated Power}

When the people have formed a Constitution, they retain those rights which they have not expressly delegated.

$$
\text { -James Madison } 64
$$

Although far less important in constitutional argument today, at the time of the Founding (and for many decades afterwards) the question of delegated sovereignty was of critical importance in determining the nature and extent of federal power. ${ }^{65}$ The concept of delegated sovereign power was not a new idea in 1787; the subject was as old as international law itself. It was a matter of historical fact that sovereign entities occasionally delegated away aspects of their sovereign authority in order to gain the benefits of a treaty or compact between independent nations. In a treaty between sovereign authorities, however, the sovereign was presumed to have delegated away only those powers expressly enumerated in the treaty-and the delegation was to be strictly construed.

At the time of the Founding, this theory of strictly construed delegated power had been recently articulated by one of the most influential legal theorists of that generation. In 1758, Emmerich de Vattel published his Le Droit des Gens ("The Law of Nations"). ${ }^{66}$ Here, Vattel explained that because sovereigns are presumed to have retained all sovereign powers not expressly delegated away, delegations of power were to be strictly construed. ${ }^{67}$ The founding generation was deeply influenced by Vattel's work and his treatise would continue to be well cited in legal scholarship and judicial opinions for the next one hun-

644 Annals of Cong. 934 (1794) (statement of Rep. Madison).

65 Contemporary debates regarding the proper conception of state sovereignty play a role in the Court's Eleventh Amendment jurisprudence and in the so-called "commandeering" cases limiting the power of the federal government to force states to enact or enforce federal policy. See generally Printz v. United States, 521 U.S. 898 (1997) (holding unconstitutional the Brady Act's interim provision requiring local law enforcement to conduct background checks); U.S. Term Limits, Inc. v. Thornton, 514 U.S. 779 (1995) (giving various opinions considering the nature of state sovereignty at the time of the Founding); New York v. United States, 505 U.S. 144 (1992) (holding unconstitutional the "take-title" provision of the Low-Level Radioactive Waste Policy Amendments which required states to dispose of their waste or take title and incur damages arising from it).

66 Emmerich de Vattel, The Law of Nations (Charles G. Fenwick trans., Carnegie Inst. of Wash. 1916) (1758).

67 See id. bk. I, ch. 2, § 16 (commenting on the duty of self-preservation); see also $i d$. bk. II, $\S \S 305,308$ (describing the need to narrowly construe "odious" delegations of sovereign power). 
dred years. ${ }^{68}$ In the first constitutional treatise, St. George Tucker's 1803 View of the Constitution of the United States, ${ }^{69}$ Tucker embraced Vattel's reasoning as analogous to the situation of the several states in the aftermath of the American Revolution. ${ }^{70}$ As newly "sovereign and independent" entities, the states retained all power, jurisdiction, and rights not "expressly delegated" under the Federal Constitution. Although this principle had been expressly declared in Article II of the Articles of Confederation, the idea was simply "a declaration of the law of nations." 71

For, no free nation can be bound by any law but [its] own will; and where that will is manifested by any written document, as a convention, league, treaty, compact, or agreement, the nation is bound, only according as that will is expressed in the instrument by which it binds itself. And as every nation is bound to preserve itself, or, in other words, [its] independence; so no interpretation whereby its destruction, or that of the state, which is the same thing, may be hazarded, can be admitted in any case where it has not, in the most express terms, given [its] consent to such an interpretation. ${ }^{72}$

Citing Vattel's theory of sovereign power throughout his analysis of the Constitution, ${ }^{73}$ St. George Tucker argued that powers delegated away by the people of the several states ought to be strictly construed. ${ }^{74}$ Tucker's work was extremely influential and remained the predominant treatise on the Constitution until well into the nineteenth century. ${ }^{75}$

68 For discussions of Vattel's influence on the founding generation, see DANIEL G. Lang, Foreign Policy in the Early Republic 15-16 (1985); Francis Stephen Ruddy, INTERNATIONAL LAW IN THE ENLIGHTENMENT 281 (1975).

69 St. George Tucker, View of the Constitution of the United States, in 1 BLackstone's Commentaries app. at 140 (St. George Tucker ed., Phila., William Birch Young \& Abraham Small 1803).

70 See St. George Tucker, Of the Unwritten, or Common Law, of England, in 1 BLACKSTONE's COMmentaRies, supra note 69, app. at 378, 407.

71 Id. at 408.

72 Id. at 423.

73 In addition to the above cited pages, see, for example, Tucker, supra note 69 , app. at 151 n.* (linking the work of Vattel with the Tenth Amendment); see also id. at 187 (citing Vattel in support of retained state sovereignty). There are many other examples throughout the work.

74 See id. at 154 (" $[\mathrm{T}]$ he powers delegated to the federal government, are, in all cases, to receive the most strict construction that the instrument will bear, where the rights of a state or of the people, either collectively, or individually, may be drawn in question.").

75 According to historian Saul Cornell, Tucker's Commentaries was "an instant publishing success" and "became the definitive American edition of Blackstone until midcentury." CORNELl, supra note 21, at 263. 
Vattel wrote in a continental context in which sovereignty was believed to reside in the person of the King, or at most the King-inParliament. ${ }^{76}$ Political theorists in America, however, easily translated his views of delegated sovereign power into a context in which the people, not the people's government, were considered the ultimate source of sovereign power. As Gordon Wood describes in his Creation of the American Republic, popular sovereignty gained widespread acceptance in colonial America in the period between the Revolution and the adoption of the Constitution. ${ }^{77}$ American popular sovereignty distinguished between the people and their government, with the latter serving as no more than the people's agents, with no greater power than that delegated to them by the people themselves. ${ }^{78}$ Following the Revolution, the people of each state remained an independent sovereign entity. ${ }^{79}$ These, then, were the sovereign people(s) who debated and, ultimately, delegated away a portion of their sovereign powers to the new federal government.

Tucker's work has long been associated with the so-called "compact theory" of the original Constitution-the theory that the Constitution arose out of a compact between the several states, with each retaining the right to secede at will. ${ }^{80}$ As such, Tucker's work tends to be lumped together with that of later, more radical states' rights proponents such as Calhoun and the secessionists who constructed their theories in an effort to protect the state-based institution of slavery. ${ }^{81}$ St. George Tucker, however, was an abolitionist ${ }^{82}$ and he wrote long before the rise of radical states' rights theorists like Calhoun and the nullifiers in the 1820 s and ' 30 s. Far from representing the emergence

76 See Akhil Reed Amar, Of Sovereignty and Federalism, 96 YALE L.J. 1425, 1431-32 (1987). See generally Edmund S. Morgan, Inventing the People 15, 17-77 (1988) (describing how "the divine right of Kings [gave] way to the sovereignty of the people").

77 See Wood, supra note 52, at 599-600.

78 See generally 1 ACKerman, supra note 28, at 3-33 (describing the "dualist" American Constitution); KRAMER, supra note 28, at 6 (arguing that the founding generation embraced the centrality of "the people" in its political ideology).

79 See The Declaration of Independence para. 31 (U.S. 1776) ("[T] hese united Colonies are, and of Right ought to be Free and Independent States . ...").

80 See Nicholas Aroney, Formation, Representation and Amendment in Federal Constitutions, 54 Ам. J. Coмp. L. 277, 308-09 (2006).

81 See, e.g., Earl M. Maltz, Majority, Concurrence, and Dissent: Prigg v. Pennsylvania and the Structure of Supreme Court Decisionmaking, 31 Rutgers L.J. 345, 358 (2000).

82 See St. George Tucker, A Dissertation on Slavery: With a Proposal for the Gradual Abolition of It, in the State of Virginia (1796), reprinted in ST. GEORGE TUCKER, VIEW OF the Constitution of the United States with Selected Writings 402, 408-09 (Clyde N. Wilson ed., 1999). 
of a new and radical view of state autonomy, Tucker's theory of retained state sovereignty and limited express federal power echoed the very arguments put forward by the advocates of the Constitution in order to secure ratification. This includes those Founders most associated with expansive views of national authority. For example, in his remarks to the New York ratifying convention, Alexander Hamilton explained in detail how the sovereign people of the several states retained all aspects of sovereignty not expressly delegated to the federal government:

In the first formation of government, by the association of individuals, every power of the community is delegated, because the government is to extend to every possible object; nothing is reserved, but the inalienable rights of mankind: but, when a number of these societies unite for certain purposes, the rule is different, and from the plainest reason-they have already delegated their sovereignty and their powers to their several governments; and these cannot be recalled, and given to another, without an express act. I submit to the committee whether this reasoning is not conclusive. ${ }^{83}$

In sum, the concept of delegated sovereign power carried with it the principle of strict construction of delegated authority. All power not expressly delegated was assumed to be retained by the sovereign. This idea predated the Constitution and continued to inform constitutional analysis well into the nineteenth century.

\section{G. The Other Meaning of Expressly Delegated Powers}

In advancing the theory of expressly delegated power, the Federalists were not (and were not understood to be) claiming that Congress would have no implied powers whatsoever. Not only would this be difficult to maintain in the face of the Necessary and Proper Clause, it was a position affirmatively rejected by the advocates of the Constitution. ${ }^{84}$ The theory of express powers was one of limited or narrow construction of delegated authority.

For example, in the Virginia convention, Edmund Randolph understood the advocates of the Constitution to be claiming that the Constitution "gives no supplementary power; but only enables them to make laws to execute the delegated powers."85 Although this allowed

832 Elliot's Debates, supra note 9, at 362-63 (emphasis added) (reporting the remarks of Alexander Hamilton to the New York ratifying convention on June 28, 1788).

84 See, e.g., The Federalist No. 33 (Alexander Hamilton), supra note 34, at 201.

85 Edmund Randolph, Debate in the Virginia Convention (June 17, 1788), in 10 The Documentary History of the Ratification of the Constitution 1338, 1347 
for the exercise of incidental powers, Randolph understood that these powers would be limited to those means that were "necessary for the principal thing." ${ }^{6}$ According to Roger Sherman, a member of the Philadelphia Convention from Connecticut, "The powers vested in the federal government are clearly defined, so that each state still retains its sovereignty in what concerns its own internal government, and a right to exercise every power of a sovereign state not particularly delegated to the government of the United States." ${ }^{87}$ In New York, Alexander Hamilton had insisted that, due to the ultimate sovereignty of the people of the United States, the federal government had only expressly delegated powers and the New York convention included the following declaration along with its notice of ratification:

[E]very Power, Jurisdiction and Right, which is not by the said Constitution clearly delegated to the Congress of the United States, or the departments of the Government thereof, remains to the People of the several States, or to their respective State Governments to whom they may have granted the same. ${ }^{88}$

The Rhode Island convention appended the same declaration (Congress had only those powers clearly delegated) along with its own notice of ratification. ${ }^{89}$ The same convention also proposed an amendment declaring that " $[\mathrm{t}]$ he United States shall guarantee to

(John P. Kaminski et al. eds., 1993) [hereinafter 10 DocumentaRy History of THE Ratification].

86 Id. at 1348 (emphasis added).

87 A Citizen of New Haven [Roger Sherman], Observations on the New Federal Constitution, New Haven Gazette, Dec. 25, 1788, at 1, reprinted in Essays on the ConstiTUtion of The United States 237, 238 (Paul Leicester Ford ed., N.Y., Burt Franklin 1970) (1892) (emphasis added). According to Herbert Storing, this was a "rather typical description of the Constitution." See Herbert J. Storing, The 'Other' Federalist Papers: A Preliminary Sketch, 6 Pol. Sci. Reviewer 215, 222 (1976).

88 Amendments Proposed by the New York Convention (July 26, 1788), in CreatING THE Bill of Rights 21, 21-22 (Helen E. Veit et al. eds., 1991); see also 1 Elloot's Debates, supra note 9, at 327-31 (reporting the ratification of New York on July 26, 1788).

89 See Ratification of the Constitution by the State of Rhode Island [hereinafter Rhode Island Ratification], in 2 Documentary History of THE CONSTITUTION OF THE United States of America 310, 316 (Wash., D.C., Dep't of State 1894); see also 1 Elliot's Debates, supra note 9, at 334 (reporting the ratification of Rhode Island on May 29, 1790); The Address and Reasons of Dissent of the Minority of the Convention of the State of Pennsylvania to Their Constituents, PA. Раскет (Phila., Pa.), Dec. 18, 1787, at 1 [hereinafter Reasons of Dissent], reprinted in 2 The Documentary History of THE RATIFiCATION OF THE CONSTITUTION 617, 624 (Merrill Jensen et al. eds., 1976) ("That the sovereignty, freedom, and independency of the several states shall be retained, and every power, jurisdiction, and right which is not by this constitution expressly delegated to the United States in Congress assembled."). 
each state its sovereignty, freedom and independence, and every power, jurisdiction and right, which is not by this Constitution expressly delegated to the United States."90

In sum, in order to counter concerns about unchecked federal power, the advocates of the Constitution maintained that the Congress would have no more than expressly delegated powers. This did not mean that Congress would have no implied powers whatsoever, but that the implied means would be limited to those "clearly implied" or "necessarily incident" to the enumerated power. This rule of strict construction of delegated power flowed from the fundamental principle of popular sovereignty: all powers delegated from a sovereign authority must be strictly or narrowly construed. As Tunis Wortman wrote in his 1800 treatise on the liberty of the press:

The objects of federal jurisdiction are specifically defined. The powers vested in the general Government are such as are expressly and particularly granted by the Constitution, or such as flow in obvious and necessary consequence from the authorities which are thus expressly conferred.

Powers claimed by implication should be such as follow from evident and necessary construction, and not in consequence of distant or conjectural interpretation. Much latitude cannot be admitted upon the occasion without endangering Public Liberty and destroying the symmetry of our Political System. ${ }^{91}$

\section{H. A Preexistent Principle}

Federalist assertions that Congress had only expressly delegated power were made throughout the states in every available medium, including newspapers, pamphlets, public speeches, and legislative debate. All of this occurred, moreover, prior to the adoption of the Tenth Amendment. Accordingly, it is not surprising to find evidence that even without the adoption of the Bill of Rights, the proper construction of the original Constitution nevertheless included the principle of expressly delegated power. As the Maryland Court of Appeals explained in 1790, a year before the ratification of the Bill of Rights: "Congress has no power but what is expressly delegated to them by the

90 Rhode Island Ratification, supra note 89 , at 316.

91 Tunis Wortman, A Trfatise Concerning Political Enquiry, and the Liberty of the Press 212 (photo. reprint 2003) (1800). Wortman goes on to cite the First, Ninth, and Tenth Amendments as "relat [ing] to the immediate subject of discussion [the power of the federal government to enact libel laws]. ${ }^{\prime} I d$. at 220 . He also rejects the idea that particular restrictions on power can be construed to imply otherwise affirmative powers and cites the eleventh and twelfth articles of amendment as declaratory provisions that did not alter previous grants of power. See id. at 223-26. 
new government. The states retain all power not delegated, and from the exercise of which they are not restrained by the new government."92

Even earlier, in June of 1789, the editors of the New York Packet (which also published The Federalist) published Observations on the New Federal Constitution, and the Alterations That Have Been Proposed as Amendments. ${ }^{93}$ The editorial, which was published in Massachusetts as well as New York, describes the Constitution as preserving the sovereignty of the states and, accordingly, limiting federal authority to expressly enumerated powers: "[T] he powers vested in the federal government are particularly defined, so that each State still retains its sovereignty in what concerns its own internal government, and a right to exercise every power of a Sovereign state, not expressly delegated to the government of the United States."94

According to Federalist Robert Goodloe Harper during the 1804 House impeachment proceedings against Samuel Chase:

But it must be recollected, Mr. President, that the constitution is a limited grant of power; and that it is of the essence of such a grant to be construed strictly, and to leave in the grantors all the powers, not expressly, or by necessary implication granted away. In this manner has the constitution always been construed and understood: and although an amendment was made, for the purpose of expressly declaring and asserting this principle, yet that amendment was always understood by those who adopted it, and was represented by the eminent character who brought it forward, as a mere declaration of a principle inherent in the constitution, which it was proper to make, for the purpose of removing doubts and quieting apprehensions. ${ }^{95}$

Harper spoke a decade after the adoption of the Constitution and the Bill of Rights, and in the aftermath of a grand public debate regarding

92 Donaldson v. Harvey, 3 H. \& McH. 12, 19 (Md. 1790). The opinion is by Judge Jeremiah Townley Chase, not to be confused with Judge Samuel Chase who served on the same Maryland court. Judge Chase had voted against the proposed Constitution at the Maryland convention due to concerns about the impact on states' rights. See Charles W. Smith, JR., Roger B. Taney 7 (1936). Although Chase's antifederalism no doubt influenced his reading of the Constitution, it nevertheless echoed assurances made by Federalists during the ratification debates.

93 A Citizen of New Haven [Roger Sherman], Observations on the New Federal Constitution, and the Alterations That Have Been Proposed as Amendments (pts. 1 \& 2), N.Y. PaCket, Mar. 20, 1789, at 3, N.Y. PACKet, Mar. 24, 1789, at 2.

94 Id:; Observations, SAlem Mercury, supra note 54.

952 Samuel H. Smith \& Thomas lloyd, Trial of Samuel Chase 257 (Da Capo Press 1970) (1805). 
the proper construction of federal power. ${ }^{96}$ His views nevertheless coincide with the original arguments used to support the ratification of the Constitution. As we shall see, James Madison himself insisted, even before the addition of the Bill of Rights, that the implied powers of Congress were to be strictly construed on the grounds that the state conventions had been promised that Congress had only expressly delegated power. ${ }^{97}$ The restrictions in the Bill were to be added ex abundanti cautela - for greater caution.

\section{The Framing and Original Understanding of the Tenth AMENDMENT}

\section{A. The State Convention Declarations and Proposed Amendments}

Despite the Federalists' repeated assurances that the proposed Constitution granted only limited or expressly delegated power, many remained unconvinced. Some Antifederalists, of course, were unalterably opposed to the Constitution. ${ }^{98}$ Others, however, were open to being persuaded to be in favor of the Constitution, provided that certain safeguards were put in place. In Virginia, although Governor Edmund Randolph rejected the exaggerated Antifederalist claim that the Constitution granted Congress general police powers, ${ }^{99}$ he nevertheless remained convinced that provisions like the Necessary and Proper Clause opened the door to dangerous (if erroneous) interpretations of enumerated federal authority. ${ }^{100}$ According to Randolph, the so-called "sweepings clause" was "ambiguous, and that ambiguity may injure the States. My fear is, that it will by gradual accessions gather to a dangerous length."101 Rather than rejecting the Constitution, however, Randolph suggested that such ambiguities be resolved either by public declarations or through the addition of amendments to the Constitution. ${ }^{102}$

96 See infra Part III.

97 See infra note 169 and accompanying text.

98 See LEVy, supra note 30, at 42 (discussing the efforts of some Antifederalists to "sabotage the Bill of Rights").

99 Randolph, supra note 85, at 1338, 1348 ("Is it not then fairly deducible, that [the federal government] has no power but what is expressly given it?").

100 See id.

101 Id. at 1353.

102 See id. at 1354; see also Edmund Randolph, Remarks at the Virginia Convention (June 24,1788 ), in 10 DOCumentaRY History OF THE RATIFICATION, supra note 85, at 1473,1483 (supporting the adoption of a provision declaring the sovereignty of the people, thus securing the principle that "[a]ll rights are therein declared to be completely vested in the people, unless expressly given away"). 
Randolph's demand for express clarification echoed similar demands from a number of state conventions. ${ }^{103}$ Even if the Federalists could be taken at their word that the proposed Constitution granted no more than expressly enumerated powers, declarations making this principle explicit ought to be adopted, if only for "greater caution." 104 Of all the proposed amendments, the most common was one calling for an express declaration of the people's reserved powers and rights. According to Samuel Adams, a reservation clause is " $a$ summary of a bill of rights." 105 In the Virginia convention, Patrick Henry similarly declared, "[A] Bill of Rights may be summed up in a few words. What do they tell us? - That our rights are reserved."106

Not surprisingly, a clause reserving all powers not expressly delegated to the federal government was generally high on the list for those states proposing amendments. Leading Massachusetts' list, for example, was a provision which "explicitly declared that all Powers not expressly delegated by the aforesaid Constitution are reserved to the several States to be by them exercised." 107 So too for New Hamp-

103 In the end, eight states submitted proposed amendments, all of which included provisions declaring the retained sovereignty of the people and limiting the construction of delegated federal power. See The Complete Bill of Rights, supra note 34 , at $674-75$.

104 See The Virginia Convention Debates (June 27, 1788), in 10 Documentary HisTORY OF THE RATIFICATION, supra note 85 , at 1550, 1553-56 (listing Virginia's proposed amendments to the Constitution); see also Letters of Centinel No. 2, supra note 51, at 147 ("Mr. Wilson tells you, that every right and power not specifically granted to Congress is considered as withheld. How does this appear? Is this principle established by the proper authority? Has the Convention made such a stipulation? By no means.").

105 The Massachusetts Convention Debates (Feb. 1, 1788), in 6 The Documentary History of the Ratification of the Constitution 1390, 1395 (John P. Kaminski et al. eds., 2000) [hereinafter 6 DocumENTARY HisToRy OF THE RATIFICATION] (emphasis added) (response of Mr. Adams to Mr. Bowdoin of Dorchester); see also 2 Eluiot's Debates, supra note 9, at 130-31 (reporting the statement of Samuel Adams before the Massachusetts convention on February 1, 1788).

106 Patrick Henry, Remarks at the Virginia Convention (June 16, 1788), in 10 DocUMENTARY History OF THE RATIFICATION, supra note 85, at 1299, 1331.

107 See Massachusetts' Form of Ratification (Feb. 6, 1788), in 6 Documentary His TORY OF THE RATIFICATION, supra note 105 , at 1469, 1469. Massachusetts' proposed amendments were widely published in newspapers throughout the states. See, e.g., Legislative Proceedings, Cumberland Gazette (Portland, Me.), Feb. 7, 1788, at 1; Legislative Proceedings, Mass. Gazette (Boston, Mass.), Feb. 5, 1788, at 1; see also The Massachusetts Convention Debates, supra note 105, at 1395 ("Your Excellency's first proposition is, 'that it be explicitly declared that all powers not expressly delegated to Congress, are reserved to the several states to be by them exercised.' This appears in my mind to be a summary of a bill of rights ...."). 
shire. ${ }^{108}$ Maryland likewise proposed an amendment declaring " $[\mathrm{t}]$ hat Congress shall exercise no power but what is expressly delegated by this constitution." 109 The Convention then supplied its understanding that such an amendment would accomplish a strict construction of federal power:

By this amendment, the general powers given to Congress by the first and last paragraphs of the 8th sect. of art. I, and the second paragraph of the 6th article, would be in a great measure restrained: those dangerous expressions by which the bills of rights, and constitutions of the several states may be repealed by the laws of Congress, in some degree moderated, and the exercise of constructive powers wholly prevented. ${ }^{110}$

Finally, Pennsylvania's proposed amendment clearly linked strict construction of federal power to the retained rights of sovereignty: "That the sovereignty, freedom, and independency of the several states shall be retained, and every power, jurisdiction, and right which is not by this constitution expressly delegated to the United States in Congress assembled." 111

Again, these amendments were not proposals to alter the Constitution's grants of federal authority. Instead, they reflected a principle which, according to the Federalists, already inhered in the idea of delegated power. This explains why some states like New York and Rhode Island believed a "declaration of understanding" was sufficient. ${ }^{112}$ Similarly, the South Carolina convention declared its understanding of delegated federal power even in the absence of amendments: "This Convention doth also declare, that no section or paragraph of the said Constitution warrants a construction that the states do not retain every power not expressly relinquished by them, and vested in the general government of the Union."113

Finally, these proposed amendments and declarations did not maintain that Congress had no other powers besides those specifically enumerated in the Constitution. By "expressly delegated" powers, the state conventions were taking Federalists on their word; Congress could exercise only those powers clearly or necessarily incident to an expressly enumerated power.

108 See 1 Elliot's Debates, supra note 9, at 325-26.

109 See $2 \mathrm{id}$. at 550 . Maryland's proposed amendments also were widely published. See, e.g., From the Maryland Gazette. To the People of Maryland, PA. PACket (Phila., Pa.), May 8,1788 , at 2.

110 From the Maryland Gazette. To the People of Maryland, supra note 109.

111 Reasons of Dissent, supra note 89, at 624.

112 See 1 Elliot's Debates, supra note 9, at 327-31, 334-37.

113 See id. at 325. 


\section{B. The Virginia Ratifying Convention}

As had other state conventions, the Virginia convention proposed an amendment reserving all nondelegated power to the states. Virginia's proposal, however, left out the word "expressly."114 When pressed to add the term, Edmund Randolph insisted that this particular phrase had been interpreted in an unduly restrictive manner under the Articles of Confederation. ${ }^{15}$ In the end, efforts to add the term failed. Virginia's rejection of "expressly delegated power" seems significant because Madison helped to draft Virginia's proposed amendments and he relied on Virginia's proposal when he produced his own draft of the Tenth Amendment-a draft which also omitted the term "expressly." 116

Although the Virginia convention seems to have intentionally omitted the word "expressly," before the convention adjourned both Randolph and Madison insisted that Congress nevertheless was limited to "expressly delegated power." In response to Antifederalist arguments that adding a Bill of Rights would imply otherwise unlimited federal power, ${ }^{117}$ Edmund Randolph quoted Virginia's proposed declaration that "all power comes from the people, and whatever is

114 The Virginia Convention proposed the addition of two interlocking amendments:

That each State in the Union shall respectively retain every power, jurisdiction and right, which is not by this Constitution delegated to the Congress of the United States, or to the departments of the Federal Government.

That those clauses which declare that Congress shall not exercise certain powers, be not interpreted in any manner whatsoever, to extend the powers of Congress, but that they may be construed either as making exceptions to the specified powers where this shall be the case, or otherwise, as inserted merely for greater caution.

The Virginia Convention Debates, supra note 104, at 1553-56. A separate draft of Virginia's proposed amendments does include the term "expressly." See Draft Structural Amendments to the Constitution (June 27, 1788), in 10 Documentary History OF the Ratification, supra note 85 , at 1547,1548 . The "Wythe Committee" draft, reproduced above, does not and this seems more in keeping with the remarks made both during the Virginia debates and later by James Madison. See supra notes 86-87 and accompanying text; infra notes 120-22, 162-76 and accompanying text.

115 See Randolph, supra note 102, at 1485 ("When we see the defects of [the old Article II], are we to repeat it? Are those Gentlemen zealous friends to the Union, who profess to be so here, and yet insist on a repetition of measures which have been found destructive to it?").

116 See James Madison, Speech in Congress Proposing Constitutional Amendments (June 8, 1789), in James Madison: Writings 437, 444 (Jack N. Rakove ed., 1999).

117 See Randolph, supra note 102 , at 1485 . 
not granted by them, remains with them."118 He then asked, "Could you devise any express form of words, by which the rights contained in the Bill of Rights of Virginia could be better secured, or more fully comprehended? . . . All rights are therein declared to be completely vested in the people, unless expressly given away." 119

To Randolph, a declaration of retained popular sovereignty by definition limited the powers of government to those expressly enumerated. Soon after Randolph spoke, James Madison rose and declared that " $\mathrm{t}]$ he observations by [Edmund Randolph], on that subject, correspond precisely with my opinion. ... [E]very thing not granted is reserved." 120 If Madison's statement seems ambiguous in regard to expressly delegated power, soon afterward (before the Bill of Rights was officially ratified), he publicly declared that the state conventions had been promised a government of only "expressly delegated power."121 In yet another public speech delivered only three years later, Madison again declared that not only had the principle of expressly delegated power been promised to the states, the addition of the Ninth and Tenth Amendments enshrined this very principle. ${ }^{122}$

\section{Summary of the State Conventions}

Almost every state convention submitted along with its notice of ratification a list of declarations or proposed amendments (or both). Among the most common of these were declarations or amendments mirroring the language of Article II and the limited delegation to Congress of only express powers. Although the Virginia proposals lacked the term "expressly," Madison and other Federalists insisted that the principle of "expressly delegated power" remained an inherent part of the proposed Constitution.

118 Id. at 1483.

119 Id. Note that Randolph equates "giving away a right" with "delegating a power." The common understanding at the time of the Founding was that rights began where powers left off, and vice versa. Abandoning a right by definition meant assigning a power. See generally Lash, Original Meaning, supra note 29, at 374 n.203 (arguing that "the Founders broadly shared the view that rights and powers were directly dependent"). As Madison put it during his speech introducing the Bill of Rights, the concern was that unenumerated rights might be assumed to have been "assigned" into the hands of the government. See Madison, supra note 116, at 448-49. 120 James Madison, Remarks at the Virginia Convention (June 24, 1788), in 10 DOCumentaRy History of THE Ratification, supra note 85, at 1473, 1501-02.

121 See infra note 169 and accompanying text.

122 See infra notes 162-69 and accompanying text (discussing Madison's 1791 speech against the Bank of the United States). 
Historians have tended to dismiss such proposals or declarations as the wishful thinking of the "losers" in the struggle over the Constitution. ${ }^{123}$ Having canvassed the assurances of the Federalists in the debates, we can see this is not correct. When those anxious to preserve broad autonomy over local self-government insisted that the Constitution granted only expressly enumerated powers, they were repeating the assurances of the advocates of the proposed Constitution. This is not wishful thinking: it is reliance. ${ }^{124}$

\section{Drafting the Tenth Amendment}

Having explored the variable meaning of "expressly delegated powers," we are now in a position to revisit the House debates over the proper language of what would become the Tenth Amendment. Consider once again the exchange between Madison and Tucker:

Mr. TUCKER proposed to amend the proposition, by prefixing to it "all powers being derived from the people." He thought this a better place to make this assertion than the introductory clause of the Constitution, where a similar sentiment was proposed by the committee. $\mathrm{He}$ extended his motion also, to add the word "expressly," so as to read "the powers not expressly delegated by this Constitution."

Mr. Madison objected to this amendment, because it was impossible to confine a Government to the exercise of express powers; there must necessarily be admitted powers by implication, unless the Constitution descended to recount every minutiae. $\mathrm{He}$ remembered the word "expressly" had been moved in the convention of Virginia, by the opponents to the ratification, and, after full and fair discussion, was given up by them, and the system allowed to retain its present form.

Mr. TUCKER did not view the word "expressly" in the same light with the gentleman who opposed him; he thought every power to be

123 See, e.g., CoRnell, supra note 21, at 244-45.

124 Some Antifederalists, of course, went further and insisted that the Constitution included no such limits-but these arguments were meant to derail ratification and force a second convention. See Address by Denatus, VA. Indep. Chron., June 11, 1788, reprinted in 5 THE COMPLETE ANTI-FEDERALIST, supra note 32, at 260, 263. The requisite votes for ratification were attained due to the successful argument of the Federalists that no such unlimited power had been granted. In order that this promise not be forgotten, the conventions submitted their declared understanding that the Federalists were telling the truth, or insisted on amendments declaring the same. Even if the Federalists had in fact dissembled in order to gain ratification, the reasonable understanding of the ratifiers, as Madison later explained, controlled the original understanding of the document. See supra note 26 and accompanying text. 
expressly given that could be clearly comprehended within any accurate definition of the general power.

Mr. TUCKER's motion being negatived,

Mr. Carroll proposed to add to the end of the proposition, "or to the people;" this was agreed to. ${ }^{125}$

Tenth Amendment scholars who analyze the above colloquy invariably focus on Tucker's failed attempt to add the term "expressly." Notice, however, that Tucker's primary purpose was to add a statement of popular sovereignty to the Tenth Amendment. ${ }^{126}$ The addition of the term "expressly" was Tucker's secondary recommendation. Tucker's primary goal of adding a statement of retained sovereign power has gone unnoticed in Tenth Amendment scholarship. His success in doing so, however, is critical to understanding the ultimate nature of the clause and I discuss it in full below.

First, however, notice how the colloquy between Tucker and Madison illustrates how the same term could be understood in different ways. Madison opposed the addition of the term "expressly" due to his belief that the addition might be construed to deny the government even those means "clearly comprehended" by the express grant. ${ }^{127}$ As Madison put it in Federalist No. 44, adding such a term might lead to accusations that Congress had "violat[ed] the Constitu-

1251 AnNals of Cong. 761 (Joseph Gales ed., 1834) (emphases added). There is a discrepancy here among different reporters. The Annals of Congress reports Daniel Carroll of Maryland making the motion to add "or to the people." See id. The Gazetle of the United States, on the other hand, reports that Elbridge Gerry made the motion and that Carroll opposed it on the grounds that it "tended to create a distinction between the people and their legislatures." Congressional Proceedings, GAZETTE U.S. (New York, N.Y.), Aug. 22, 1789, at 149, reprinted in Creating the Bill of Rights, supra note 88, at 192, 193.

126 Calvin Johnson assumes that the addition of the popular sovereignty language to the Tenth Amendment must have come from Federalists-Johnson in fact goes so far as to claim that the language amounted to a "slap in the face" to the Antifederalists since they believed in states' rights and not the rights of the people. See JoHnson, Righteous ANGER, supra note 6, at 175 . The record, of course, expressly shows the opposite is true: the language was first suggested by the same member who sought to add the term "expressly" to the Tenth Amendment.

127 This reading seems to be supported by the report of the debate in the Gazette of the United States in which Roger Sherman of Connecticut supports Madison's objection on the ground that "all corporations are supposed to possess all the powers incidental to their corporate capacity: It is not in human wisdom to provide for every possible contingency." Congressional Proceedings, supra note 125, at 193. Sherman's final point means that he believed the addition of the term would require the Constitution to expressly "provide for every possible contingency." Once again, Tucker did not share the same reading of "expressly" for he believed it allowed the government sufficient flexibility to use those implied means necessarily incident to the express delegation of power. See id. 
tion, by exercising powers indispensably necessary and proper, but, at the same time, not expressly granted." 128 Madison viewed the term as inescapably linked to the language of Article II and its attendant problems. The Virginia convention had rejected the term "expressly" precisely because men like Randolph and Madison believed it would incorporate a term that had hamstrung the earlier Congress. ${ }^{129}$

Tucker, on the other hand, "did not view the word 'expressly' in the same light" as Madison. According to Tucker, it was understood that expressly delegated powers allowed for the exercise of all specific powers "clearly comprehended within any accurate definition of the general power." Adding the term would therefore not preclude the exercise of implied powers-it would, however, control their scope.

Tucker did not disagree with Madison that Congress was to have a certain degree of implied powers-indeed his comments show he clearly believed "expressly" delegated powers included those implied means necessarily incident to the grant. For his part, Madison did not oppose a narrow construction of implied congressional means. His worry was that the term might be read to reject all implied means-an unreasonable constraint on the exercise of congressional power. Put another way, there is no evidence that Madison or anyone else in House of Representatives rejected the general idea that Congress had none but expressly delegated powers properly understood.

In fact, before Congress was through drafting the Ninth and Tenth Amendments, the text of both amendments would be altered in a manner that emphasized the need to strictly construe the expressly delegated powers of the sovereign people.

\section{E. Popular Sovereignty and the Tenth Amendment}

At the time that Tucker spoke, the House was considering adding a statement of popular sovereignty to the Preamble to the Constitution. ${ }^{130}$ Tucker objected to this placement on the ground that the Preamble was not actually part of the Constitution and therefore not binding upon the government. ${ }^{131}$ Instead, Tucker wished to make the declaration a part of the official (and binding) Bill of Rights. ${ }^{132}$ Tucker's request echoed similar requests by a number of state conventions that had asked for the addition of an express statement of popu-

128 The Federalist No. 44 (James Madison), supra note 34, at 284.

129 See, e.g., Randolph, supra note 85, at 1348.

130 See Madison, supra note 116, at 441.

131 See Congressional Proceedings, Daily Advertiser (New York, N.Y.), Aug. 15, 1789, at 2, reprinted in Creating the Bill of Rights, supra note 88, at 128, 128.

132 See id. 
lar sovereignty. Virginia, ${ }^{133}$ North Carolina, ${ }^{134}$ and Rhode Island ${ }^{135}$ had each proposed adding a declaration to the effect that "all power is naturally invested in, and consequently derived from, the people; the magistrates therefore are their trustees and agents, and at all times amenable to them." Tucker's idea of combining the language of popular sovereignty with a statement of reserved powers tracked the approach of the New York convention which had proposed:

That the powers of government may be reassumed by the people whensoever it shall become necessary to their happiness; that every power, jurisdiction, and right, which is not by the said Constitution clearly delegated to the Congress of the United States . . . remains to the people of the several states . . . ${ }^{136}$

A declaration of the people's sovereign power did more than merely remind the government of its source of authority. As the people's agent, the government could claim no powers but those "clearly" 137 or "expressly"138 delegated to it. As James Iredell put it, "[The Constitution] is a declaration of particular powers by the people to their representatives, for particular purposes. It may be considered as a great power of attorney, under which no power can be exercised but what is expressly given."139 This echoes Edmund Randolph's assertion that adding a statement declaring the reserved powers of the sovereign people would, by definition, limit the government to expressly delegated powers, for "[a]11 rights are therein declared to be completely vested in the people, unless expressly given away." 140 To Randolph, the link between a declaration of popular sovereignty and a government of expressly delegated powers was of critical importance:

If I did believe, with the Honorable Gentleman, that all power not expressly retained was given up by the people, I would detest this Government. But I never thought so, nor do I now. If in the ratification, we put words to this purpose-that all authority not given, is retained by the people, and may be resumed when perverted to their oppression; and that no right can be cancelled, abridged, or restrained, by the Congress, or any officer of the United States; I

\footnotetext{
133 See 3 Elliot's Debates, supra note 9, at 657.

134 See 4 id. at 243.

135 See 1 id. at 334.

136 Id. at 327.

137 See id. at $327,334$.

138 For proposals by Massachusetts, New Hampshire, Maryland, and Pennsylvania, see supra notes $107-11$ and accompanying text.

1394 Elliot's Debates, supra note 9, at 148.

140 Randolph, supra note 102, at 1483 (emphasis added).
} 
say, if we do this, I conceive that, as this stile of ratification would manifest the principles on which Virginia adopted it, we should be at liberty to consider as a violation of the Constitution, every exercise of a power not expressly delegated therein. ${ }^{141}$

Understanding the link between the concept of retained sovereign power and the limited construction of delegated power explains why Thomas Tucker's primary goal was to add a declaration that all nondelegated powers were reserved to the states or to the people. By definition, delegated sovereign power was to be narrowly construed. Tucker's secondary proposal, adding the term "expressly," simply underlined his primary purpose. Although the particular term "expressly" was rejected on the grounds that it too closely followed the crippling language of the Articles of Confederation, the House ultimately voted to add the words "or to the people." 142 By doing so, the principle of popular sovereignty and its attendant implicit restrictions on federal power became an enforceable part of the Constitution. ${ }^{143}$

The relationship between the popular sovereignty addition to the Tenth Amendment and the issue of expressly delegated power has been completely missed by contemporary Tenth Amendment scholarship. Those scholars who note the addition of the popular sovereignty language to the Tenth Amendment generally view it as a vague reference to individual rights, thus ignoring the fact that it was introduced at the same time and by the same man who sought to limit the new government to expressly delegated powers. ${ }^{144}$

Indeed, the final words of the Tenth Amendment may seem vaguely out of place in a clause seemingly devoted to states' rights.

141 Edmund Randolph, Remarks at Virginia Convention (June 21, 1788), in 10 DOCUMENTARY History OF THE RATIFICATION, supra note 85, at 1440, 1455-56 (footnote omitted).

1421 Annals of Cong. 761 (Joseph Gales ed., 1834).

143 The same principle would be expressed in the Tenth Amendment's sibling, the Ninth Amendment.

144 Those few scholars who have focused on the addition of the "or to the people" provision have in fact moved in the precisely opposite direction of that envisioned by Tucker, and attempted to read the clause in tandem with the Ninth Amendment as guarding individual natural rights. See, e.g., David N. Mayer, The Natural Rights Basis of the Ninth Amendment: A Reply to Professor McAffee, 16 S. ILL. U. L.J. 313, 317 n.13 (1992); Norman Redlich, Are There "Certain Rights ... Retained by the People"?, 37 N.Y.U. L. REv. $787,806-07$ (1962). For a critique of this view see Lash, Original Meaning, supra note 29, at 360 n.422 (suggesting that the Ninth Amendment is best read as an independent check on the expansion of federal power through judicial "constructive enlargement"); Thomas B. McAffee, The Federal System as a Bill of Rights: Original Undersiandings, Modern Misreadings, 43 VILL. L. REv. 17, 19-27 (1998) (taking the view that "the purpose of the Ninth Amendment is to preserve the federal structure against a unique threat posed by enumeration of significant limits on federal power"). 
We read terms like "the people" through the lens of nationalism-a nationalism hard-won through the struggle of a bloody civil war. Today, "the people" is generally understood to refer to the unified people of the United States of America. When the Tenth Amendment was drafted and adopted, however, the only conventions of "the people" that had ever been held were those involving the people of individual states. It was "the people" of Massachusetts (or Virginia or New York) who held the sovereign power to ratify or reject the proposed Constitution. Thus, the reference to "the people" in the Tenth Amendment was generally understood at the time (and later) as a reference to the people of the several states. ${ }^{145}$ All powers not delegated to the federal government, or denied to the states, were reserved to the people of each state-who in turn could delegate that power to their respective state governments if they wished to do so. This is how courts and commentators have read the Tenth Amendment for over two hundred years. ${ }^{146}$

It did not matter, moreover, whether one viewed the proposed Constitution as creating a single national "people" or as preserving the individual sovereignty of the "peoples" of the several states (or both, as Madison believed). ${ }^{147}$ A single national people was fully capable of dividing power between a national and local government. ${ }^{148}$ Where the local governments were assumed to have broad unenumer-

145 See Kurt T. Lash, The Inescapable Federalism of the Ninth Amendment, 93 Iowa L. Rev. 801, 820 n.63 (2008); see also, e.g., 1 Elliot's Debates, supra note 9, at 327 (containing New York's proposed declarations and notice of ratification stating that "every power, jurisdiction, and right, which is not by the said Constitution clearly delegated to the Congress of the United States, or the departments of the government thereof, remains to the people of the several states, or to their respective state governments" (emphasis added)). Antifederalists in Virginia attempted to make hay out of the fact that the addition of "or to the people" might imply the creation of a unified national people, thus obliterating the independent existence of the states. See Entry of December 12, 1789, in Journal of the Senate of the Commonwealth of Virginia 60, 64 (Richmond, Thomas W. White 1828). The exaggerated concern was part of an effort to discredit the proposed Bill of Rights in order to fuel the drive for a second national convention wherein Antifederalists could restructure the Philadelphia document. See Lash, supra, 840-41.

146 See Printz v. United States, 521 U.S. 898, 919 (1997); New York v. United States, 505 U.S. 144, 155 (1992); Nat'l League of Cities v. Usery, 426 U.S. 833, 842 (1976); A.L.A. Schechter Poultry Corp. v. United States, 295 U.S. 495, 529 (1935); Hammer v. Dagenhart, 247 U.S. 251, 295 (1918); McCulloch v. Maryland, 17 U.S. (4 Wheat.) 316, 406 (1819); 2 STORY, supra note 4 , § 1907, at 652.

147 See infra notes 261-67 and accompanying text.

148 See The Federalist No. 39 (James Madison), supra note 34, at 246. 
ated police powers, ${ }^{149}$ the federal government was understood as having only specific delegated powers. All other powers were reserved to the people of the several states. ${ }^{150}$ Thus, no matter how one viewed the principle of popular sovereignty-as the will of a single people or as the will of the many people(s) of the United States-power delegated to the national government was to be strictly construed, as were all delegations of power from the sovereign to the sovereign's agents. As Madison put it, "When the people have formed a Constitution, they retain those rights which they have not expressly delegated."151 Finally, notice that both the Ninth and Tenth Amendments end with a reference to "the people." 152 As I explain in detail elsewhere, these two Amendments were read in tandem as calling for a strict construction of federal power. ${ }^{153}$ This is not surprising once we understand the nature of power delegated by the people. Standing behind all such delegations are the sovereign people who were assumed to have retained all power and rights not expressly delegated away.

\section{Post-Submission Commentary}

The first decade of the Constitution witnessed the emergence of two competing views of federal power. The first, represented by Founders like James Madison and Thomas Jefferson, stressed the commitment made to the state ratifying conventions that federal power would be strictly construed. The second, most associated with Alexander Hamilton, James Wilson, and the Federalist Party under President John Adams, pressed for a broad reading of Congress' enumerated powers. These two approaches emerged early on in the public debate over the establishment of the Bank of the United States. The clash of competing visions of federal power would reach its climax in the con-

149 See 2 Elliot's Debates, supra note 9, at 362-63 ("In the first formation of government, by the association of individuals, every power of the community is delegated, because the government is to extend to every possible object; nothing is reserved but the unalienable rights of mankind: but, when a number of these societies unite for certain purposes, the rule is different, and from the plainest reason-they have already delegated their sovereignty and their powers to their several governments; and these cannot be recalled ....").

150 At least until such time that a combination of both the national and state people amend the Constitution. See U.S. Const. art. V; The Federalist No. 39 (James Madison), supra note 34, at 246 (discussing how the procedures for amendment involve a combination of national and state majorities).

1514 ANNAls of Cong. 934 (1794) (statement of Rep. Madison).

152 U.S. ConsT. amend. X; id. amend IX.

153 See supra note 143 and accompanying text; see also infra notes 162-86 and accompanying text (discussing the joint citation of the Ninth and Tenth Amendments as establishing the principle of expressly delegated power). 
troversy surrounding the enactment of the Alien and Sedition Acts. The first decade of the Constitution would close with a decisive rejection of Hamilton's nationalism and a reaffirmation of the promised principle of expressly delegated power.

\section{A. The Bank Controversy}

The first major debate over federal power occurred in regard to the proposed chartering of a national bank. ${ }^{154}$ James Madison and Edmund Randolph believed the creation of the Bank was beyond the legitimate powers of Congress. Although both men conceded that Congress had both express and implied powers, the means chosen by Congress to advance its enumerated ends had to be sufficiently related to its express authority and not merely "expedient" towards advancing those ends. ${ }^{155}$ Thomas Jefferson was even more insistent that the Bank exceeded federal power, claiming that under the Tenth Amendment, Congress could authorize only those means absolutely necessary to advancing an expressly enumerated power. ${ }^{156}$ The opinion that ultimately convinced President Washington to sign the bank bill, ${ }^{157}$ however, was that of Alexander Hamilton. Despite his insistence during the ratification debates that Congress had only limited enumerated power, Hamilton now rejected the narrow construction of federal power advocated by Madison, Randolph, and Jefferson, and, in language John Marshall would pick up on years later, argued that Congress possessed any means which were "needful, requisite, incidental, useful, or conducive" to advancing an enumerated end. ${ }^{158}$ According to Hamilton:

154 For background on the debate over the First Bank of the United States, see Elkins \& MCKitRick, supra note, 35, at 223-44; KillenBecK, supra note 1, at 9-30.

155 See Letter from Edmund Randolph, U.S. Attorney Gen., to George Washington, President of the U.S. (Feb. 12, 1791), in H. Jefrerson Powell, The ConstituTION AND THE ATtorneys General 3, 8 (1999) ("Hence the rule contended for by the enemies of the bill is defective every way. It would be still more so with respect to those (if any such there be) who construe the words, 'necessary and proper,' so as to embrace every expedient power."); see also James Madison, Speech Opposing the Creation of a National Bank (Feb. 2, 1791), in JAMEs MAdison: WRITINGs, supra note 116, at 480,486 ("If implications, thus remote and thus multiplied, can be linked together, a chain may be formed that will reach every object of legislation ....").

156 See Thomas Jefferson, Opinion on the Constitutionality of a National Bank (Feb. 15, 1791), in Thomas Jefrerson: Writings 416, 416-21 (Merrill D. Peterson ed., 1984).

157 Act of Feb. 25, 1791, ch. 10, 1 Stat. 191.

158 Alexander Hamilton, Final Version of an Opinion on the Constitutionality of an Act to Establish a Bank (Feb. 23, 1791), in 8 The Papers of Alexander Hamilton 97, 102 (Harold C. Syrett ed., 1965). 
[E]very power vested in a Government is in its nature sovereign, and includes by force of the term, a right to employ all the means requisite, and fairly applicable to the attainment of the ends of such power; and which are not precluded by restrictions $\mathcal{E}^{\circ}$ exceptions specified in the constitution; or not immoral, or not contrary to the essential ends of political society. ${ }^{159}$

Foreshadowing the position Marshall would hint at in $\mathrm{McCulloch}$ and make express in Gibbons, Hamilton insisted that the only constitutional limits to federal power were those "specified" in the Constitution. ${ }^{160}$ Sensing an attempt to stretch congressional authority beyond its legitimate limits, a number of Representatives objected that the bank bill exceeded the properly construed powers of Congress. Future Virginia Governor William Branch Giles, for example,

took notice of some of the observations which had fallen from a gentleman from Connecticut respecting incidental powers, and denied that Congress possessed those powers. The general government, he said, was not a consolidating government, but a federal government, possessed of such powers as the states or the people had expressly delegated .... ${ }^{161}$

In his own speech opposing the Bank, James Madison pointed out that the state conventions had ratified the Constitution on the assumption that federal power would not receive such a "latitudinary" construction. In a passage of his speech that until now has gone unnoticed, Madison explicitly embraced the principle of expressly delegated power and tied it directly to the Ninth and Tenth Amendments:

In confirmation of his sentiments, [Madison] adduced certain passages from speeches made in several of the state conventions by those in favour of adopting the constitution. These passages were fully in favour of this idea, that the general government could not exceed the expressly delegated powers. In confirmation also of this

159 Id. at 98 (final emphasis added).

160 This seems to contradict the Ninth Amendment which declares that the restrictions on federal power enumerated in the Constitution are not the only restrictions on federal power. See Lash, Textual-Historical Theory, supra note 29, at 921.

161 Congressional Proceedings, Gen. Advertiser (Phila., Pa.), Feb. 5, 1791, at 3 [hereinafter Congressional Proceedings, Gen. Advertiser]. Three years later, Giles left no doubt that the Tenth Amendment embraced this specific principle. In a discussion regarding the power of the government to provide relief for destitute aliens: "Mr. Giles enlarged on the unconstitutionality of the power proposed to be exercised by the legislature. The scope of his argument turned on the force of an amendment to the constitution, which precludes Congress from the exercise of powers not expressly delegated." Congressional Proceedings, Greenleaf's N.Y.J., Jan. 18, 1794, at 2. 
sentiment, he adduced the amendments proposed by Congress to the constitution. ${ }^{162}$

[A] 11 these renunciations of power proceeded on a rule of construction, excluding the latitude now contended for. These explanations were the more to be respected, as they had not only been proposed by Congress, but ratified by nearly three-fourths of the states. $\mathrm{He}$ read several of the articles proposed, remarking particularly on the [Ninth and Tenth Amendments,] the former, as guarding against a latitude of interpretation-the latter, as excluding every source of power not within the constitution itself. ${ }^{163}$

The material quoted above combines two separate incomplete accounts of Madison's speech. The first paragraph comes from an account of Madison's speech published by the Federal Gazette. ${ }^{164}$ The second paragraph is from an account of the speech published a few days later in the Gazette of the United States. ${ }^{165}$ Because the later version contained a more extensive version of Madison's remarks, this is the account presented in collections of Madison's writings. ${ }^{166}$ The initial version published in the Federal Gazette, however, contains aspects of Madison's speech which were only paraphrased in the account printed in the Gazette of the United States. ${ }^{167}$

The reporter for the Gazette of the United States breaks off from Madison's actual remarks just when Madison began speaking about

162 Congressional Proceedings, FED. GAZETTE, supra note 11; see also 4 Elliot's DeBates, supra note 9, at 414 (reporting the statements of James Madison regarding the establishment of a national bank on February 2, 1791).

163 Congressional Proceedings, Gazetre U.S. (New York, N.Y.), Feb. 23, 1791, at 757 [hereinafter Congressional Proceedings, GAZETTE U.S.]. In the bracketed text, Madison referred to the "11th and 12th" Amendments. His reference reflects the early convention of referring to provisions in the Bill of Rights according to their placement on an original list of twelve proposed amendments. What we know as the Ninth and Tenth Amendments were eleventh and twelfth on that original list. See Akhil Reed Amar, America's Constitution 315 (2005).

164 Congressional Proceedings, Fed. GazeTte, supra note 11.

165 Congressional Proceedings, GAZETTE U.S., supra note 163.

166 See James Madison, Speech Opposing the Bank Bill (Feb. 2, 1791), in 13 THE Papers of James Madison 373 (Charles F. Hobson et al. eds., 1981); Madison, supra note 155 , at 480 .

167 This earlier account can also be found in Elliot's Debates. See 4 ElLIot's Debates, supra note 9, at 414. The use of Elliot's Debates, however, has fallen out of favor among legal historians due to Elliot's somewhat notorious states' rights advocacy, as noted in H. Jefferson Powell, The Principles of '98: An Essay in Historical Retrieval, 80 VA. L. Rev. 689, 689 (1994), and the gradual emergence of more complete collections of founding materials. For an example of the latter, see THE DocumentaRy History of the Ratification of the Constirution (Margaret A. Hogan et al. eds., 1976-2008). The Documentary History collection, however, does not at this time include materials on the bank debate. 
the promises made to the state conventions. At that point, the reporter inserts a parenthetical paraphrase of Madison's remarks. ${ }^{168}$ The writer for the Federal Gazette, on the other hand, reports that Madison declared the states had been promised that "the general government could not exceed the expressly delegated powers." ${ }^{69}$ The passage is obviously significant, for it presents Madison as explicitly claiming that the ratifiers in the states had relied upon the promise that the federal government would have only expressly delegated powers. The Gazette of the United States, on the other hand, includes critical information left out of the Federal Gazette, in particular Madison's insistence that the principle of expressly delegated power was made an official part of the Constitution through the adoption of the Ninth and Tenth Amendments. ${ }^{170}$ To my knowledge, these two accounts have never before been viewed in conjunction-indeed, the critical passage in the Federal Gazette regarding expressly delegated power has never been noticed at all.

In support of his claim that the states expected no more than expressly delegated power, Madison quoted "certain passages" from the Pennsylvania, Virginia, and North Carolina conventions. ${ }^{171} \mathrm{We}$ know that all of these conventions heard Federalist assurances that Congress would have only expressly enumerated powers. In North Carolina, Archibald Maclaine, Governor Samuel Johnston, and future Supreme Court Justice James Iredell all assured the convention that Congress would have none but expressly delegated powers. ${ }^{172}$ In Virginia, Edmund Randolph made the same assurances. ${ }^{173}$ In Pennsylvania, future Supreme Court Justice James Wilson apparently made a similar claim ${ }^{174}$ and the Pennsylvania convention ratified the Constitution with the expectation that amendments would soon be added,

168 Congressional Proceedings, GAZETTE U.S., supra note 163; see also Madison, supra note 155, at 489 ("Here he read sundry passages from the debates of Pennsylvania, Virginia, and North-Carolina conventions, shewing the grounds on which the constitution had been vindicated by its principle advocates, against a dangerous latitude of its powers, charged on it by its opponents.").

169 Congressional Proceedings, Fed. Gazette, supra note 11.

170 See Congressional Proceedings, GAZETTE U.S., supra note 163.

171 See Congressional Proceedings, Fed. GazeTte, supra note 11. The earlier account in the Federal Gazette reveals that the specific arguments Madison referred to were those limiting Congress to expressly enumerated powers. See id.

172 See supra notes 59-61 and accompanying text.

173 See supra notes 85-86 and accompanying text.

174 See Letters of Centinel No 2, supra note 51, at 147 ("Mr. Wilson tells you, that every right and power not specifically granted to Congress is considered as withheld. How does this appear? Is this principle established by the proper authority? Has the Convention made such a stipulation? By no means."). For a discussion of Wilson's 
with top priority being a provision limiting the government to expressly delegated power. ${ }^{175}$ After reminding the House about these assurances, Madison then pointed out that the Ninth and Tenth Amendments had been proposed in order to put in writing the promised principle of expressly enumerated powers. ${ }^{176}$

Even some of Madison's opponents on the question of a national bank agreed that the Tenth Amendment represented an underlying principle of expressly delegated power. John Vining of Delaware, for example, accepted the rules of narrow construction urged by Madison and Giles, but nevertheless insisted that power to incorporate the Bank fell within Congress' legitimate authority. According to Vining, "The constitutionality of the [Bank] . . . urged from a fair construction of those powers, expressly delegated, and from a necessary implication."177 Likewise, Fisher Ames accepted the principle of expressly enumerated powers while still supporting the Bank:

Gentlemen had noticed the amendment proposed by Congress to the Constitution as conveying the sense of the Legislature on the nature of the powers vested by that instrument; the amendment stated, that it should be declared, that the powers not expressly delegated to the General Government, and such as could be exercised by the States, should be considered as belonging to the States. But the power of establishing a National Bank, he said, could not be exercised by the States, and therefore rested no where but in the Federal Legislature. ${ }^{178}$

Notice how Ames described the Tenth Amendment as "conveying the sense of the legislature on the nature of power" delegated to the federal government. Specifically, "powers not expressly delegated to the

argument and the concept of "expressly delegated" powers, see Wood, supra note 52, at $539-40$.

175 Madison, supra note 155, at 488-89 ("[T]he [Pennsylvania, Virginia, and North Carolina] state conventions all turned on the same fundamental principle [that the powers not given were retained], and on the principle that the terms necessary and proper gave no additional powers to those enumerated.").

176 See id. at 489. For readers unfamiliar with developments in Ninth Amendment historical scholarship, it might seem odd that Madison paired the Tenth with the Ninth Amendment. Until recently, scholars have tended to view the Amendments as having very different purposes, with the Ninth guarding rights and the Tenth guarding powers. As I have discussed elsewhere, however, it appears that the two Amendments were viewed as working in conjunction to preserve the people's retained right to local self-government. See supra note 29.

177 Congressional Proceedings, Gen. Advertiser, supra note 161.

178 National Bank, Columbian Centinel (Boston, Mass.), Mar. 9, 1791, at 201; see also The Observer No. V (pt. 1), Fed. GazeTte (Phila., Pa.), Apr. 1, 1791, at 2 ("[W]hile [the Constitution] provided for the strength and common defense of the whole, it left every part in possession of the rights not expressly delegated or resigned . ..."). 
[federal] Government ... should be considered as belonging to the states." 179 Ames thus read the Tenth Amendment as declaring a preexisting limitation on the proper construction of federal power, and he conceded that the principle declared by the Tenth Amendment was one of expressly delegated federal power. ${ }^{180}$

Although Madison failed to persuade his fellows in the House (or the President) that the Bank exceeded Congress' delegated powers, his speech was widely distributed and commentators praised his defense of the principle of expressly delegated power. ${ }^{181}$ Before the

179 National Bank, supra note 178.

180 Similar statements were made by Theodore Sedgwick who argued:

The amendment proposed by Congress to the constitution had been mentioned to prove that agreeable to the sense of the federal legislature the general government had no authority to set on foot a bank: he conceived it did not go so far; the establishment of an institution that was intended to have a general operation, could only rest with the representatives of the Union.

If it was dubious whether the power contested could not be clearly deduced from the constitution, it should not, he said, be exercised: but it appeared to him clearly delegated by that instrument.

Congressional Proceedings, Fed. Gazette (Phila., Pa.), Feb. 16, 1791, at 2. Some advocates of the Bank, of course, shared Alexander Hamilton's newly announced view of federal power. See, e.g., Congressional Proceedings, Fed. Gazerte (Phila., Pa.), Feb. 15, 1791, at 2 ("The more important powers are specially granted, but the choice from the known and usual means of carrying the power into effect is left to the decision of the legislature.").

181 See An American, For the American Daily Advertiser, Dunlap's Am. Dally AdverTISER (Phila., Pa.), Feb. 16, 1791, at 2 (noting that "state governments and the people retained all powers not expressly granted by the Constitution" and praising Madison's effort against the Bank).

Madison's argument against the bank had a long life. The Richmond Enquirer reprinted the speech in its entirety when the charter was up for renewal in 1810. See Letter to the Editor, Enquirer (Richmond, Va.), Jan. 4, 1810, at 4. Following the Supreme Court's decision upholding the Second Bank of the United States in $\mathrm{McCul}$ loch, St. George Tucker planned to add a note to his revised edition of Blackstone's Commentaries acknowledging the decision, but directing his readers to Madison's speech. See St. George Tucker, Notes for Revised Version of 1 Tucker's Blackstone's Commentaries, in 1 Blackstone's CommentaRies, supra note 69, app. at 287 (handwritten notes on facing pages of Tucker's personal copy of Blackstone, located at the Earl Gregg Swem Library at the College of William and Mary). The following was to be added as note * to his discussion of the Necessary and Proper Clause:

See also, the late President Madison's Speech in Congress in February 1791 against the Bill for establishing a Bank, published in the Richmond Enquirer, vol: 6: no:73. January 4, 1810. But the question on the right of Congress to establish a Bank, with branches in the several states is put at rest, by the Decision of the Supreme Court of the United States, unanimously, in the case of McCulloch vs the State of Maryland March 1819. "That the Act to 
close of the Constitution's first decade, Justice Chase of the United States Supreme Court would issue two opinions embracing this same principle of expressly delegated power. Of the two, ${ }^{182}$ Chase's famous opinion in Calder $v$. Bull ${ }^{183}$ is most often cited in support of judicial protection of unenumerated natural rights. ${ }^{184}$ The opinion, however, includes a rarely quoted but strongly worded passage on the retained sovereignty of the people in the states and the limits of federal power:

It appears to me a self-evident proposition, that the several State Legislatures retain all the powers of legislation, delegated to them by the State Constitutions; which are not EXPRESSLY taken away by the Constitution of the United States. The establishing courts of justice, the appointment of Judges, and the making regulations for the administration of justice, within each State, according to its laws, on all subjects not entrusted to the Federal Government, appears to me to be the peculiar and exclusive province, and duty of the State Legislatures: All the powers delegated by the people of the United States to the Federal Government are defined, and No CONSTRUCTIVE powers can

incorporate the Bank of the U.S. is a law made in pursuance of the Constitution, and is a part of the supreme law of the land." and also, "That the Law passed by the Legislature of Maryland, imposing a Tax on the Bank of the U.S. is unconstitutional and void."

Id.; see also Hampden, Letter to the Editor, Rights of "the States and of the People" No. 3, Richmond Enquirer, June 18, 1819, at 2, reprinted in John Marshall's Defrense of MCCULLOCH v. MARYLAND 125, 133 (Gerald Gunther ed., 1969) (repeating Clinton's argument that incidental powers must be subordinate to an enumerated end); Hampden, Letter to the Editor, Rights of "the States and of the People" No. 2, Richmond Enquirer, June 15, 1819, at 3, reprinted in John Marshall's Defense of McCulloch v. MARYLAND, supra, at 116, 122-23 (referring to Madison's "celebrated" speech against the first bank law).

182 In addition to the case discussed in the text, Justice Samuel Chase also delivered an opinion while on circuit in which he declared:

In this country, every man sustains a two-fold political capacity; one in relation to the state, and another in relation to the United States. In relation to the state, he is subject to various municipal regulations, founded upon the State constitution and policy, which do not affect him in his relation to the United States. For, the constitution of the Union, is the source of all the jurisdiction of the national government; so that the departments of the government can never assume any power, that is not expressly granted by that instrument, nor exercise a power in any other manner than is there prescribed.

United States v. Worrall, 28 F. Cas. 774, 779 (C.C.D. Pa. 1798) (No. 16,766) (opinion of Chase, J.).

1833 U.S. (3 Dall.) 386 (1798).

184 See, e.g., Barnetr, supra note 28, at 126; Calvin R. Massey, Silent Rights 49, 158-59 (1995); Suzanna Sherry, The Founders' Unwritten Constitution, 54 U. CHI. L. Rev. $1127,1166-73$ (1987). 
be exercised by it, and all the powers that remain in the State Governments are indefinite, except only in the Constitution of Massachusetts. ${ }^{185}$

By citing the above examples (and there are others), I do not mean to claim that the principle of expressly enumerated power was uniformly embraced by all relevant parties during the first decade of the Constitution. ${ }^{186}$ Indeed, as I indicated at the opening of this Part (and as the bank debates obviously reveal) a strong counterinterpretation of broad federal power emerged during this same period. The above examples illustrate, however, that the same principle which was pressed by the Federalists in the ratifying conventions lived on after the establishment of the Constitution. Before this principle could prevail, however, it would have to overcome a very different understanding of national power-a far more nationalist interpretation that

185 Calder, 3 U.S. (3 Dall.) at 387.

186 In addition to those examples cited in this and the next subpart, see Ex parte Tate, 39 Ala. 254, 255 (1864) (George W. Gayle for petitioner) ("[T] he general government is the mere creature and agent of the States, and possesses only such powers as are expressly delegated to it, or such as are necessary to carry into effect the delegated powers."); Hortensius [George Hay], An Essay on the Liberty of the Press 6 (photo. reprint 1970) (1799) ("That the individuals selected from the mass of the people, to administer the government, possess no powers, general or special, but those which are either expressly delegated, or are necessary to carry a power expressly delegated into effect."); Letter from George Washington to Lord B. (1818), in LeTTERS FROM WASHINGTON, ON THE Constitution AND LAWs 78, 87 (A Foreigner [George Watterston] ed., Wash., D.C., Jacob Gideon 1818) ("You will easily discover, and it must be always understood, that the powers not expressly delegated, are reserved to the states and to the people. All constructive or assumed powers are considered as dangerous to the liberties of the citizen, and fatal to the rights and the union of the states."); Congressional Proceedings, NAT'L INTElligencer (Wash., D.C.), Nov. 27, 1807, at 1 ("Whatever powers and authorities are not expressly delegated by the constitution to the United States, or necessarily arising under it, shall be reserved to the states themselves or to the people."); Congressional Proceedings, N.Y. Com. Advertiser, Jan. 24, 1805, at 2. As Senator Hayne put it during the Tariff Debates of the 1820s:

Gentlemen surely forget that the supreme power is not in the government of the United States. They do not remember that the several states are free and independent sovereignties, and that all power not expressly granted to the federal government is reserved to the people of those sovereignties. When I say expressly delegated, I wish to be understood that no power can be exercised by Congress which is not expressly granted, or which is not clearly incident to such a grant.

4 Elliot's Debates, supra note 9, at 476 (reporting the remarks of Robert Hayne in April 1824). Hayne, of course, was on the historically perceived losing end of the famous Hayne-Webster debates. Whatever one makes of his arguments in terms of the politics of the 1830s, he is clearly using terms and principles that extend back to the Founding. 
relied on the omission of the word "expressly" in the Tenth Amendment.

\section{B. The Alien and Sedition Acts Controversy}

Although the issue of a national bank remained a subject of fierce debate for decades, it pales in comparison to the political controversy triggered by the adoption of the Alien and Sedition Acts. ${ }^{187}$ Passed in the midst of a political standoff with France in 1798, the Acts authorized presidential deportation of suspected subversive aliens ${ }^{188}$ and essentially criminalized public criticism of the national government. ${ }^{189}$ Outraged by what they perceived as an unconstitutional usurpation of powers reserved to the states, James Madison and Thomas Jefferson anonymously prepared their famous Virginia and Kentucky Resolutions which declared that the Acts exceeded any reasonable interpretation of federal power and violated the First Amendment's express denial of power to regulate the press. ${ }^{190}$ Because the subject was intended to be beyond federal control, the Acts violated the reserved powers declaration in the Tenth Amendment.

As the presidential election of 1800 approached, the Republican majority in the Virginia Assembly prepared a report on the Virginia Resolution and distributed it as a campaign document supporting the election of Republicans to the national Congress (and the presidency). ${ }^{191}$ Despite the dominance of Republicans in most of the state, there remained a number of Virginia districts where Federalists stood a chance of gaining seats in the next election, including one particular district where future Supreme Court Chief Justice John Marshall hoped to gain a seat in the national House of Representatives. ${ }^{192}$ The controversy over the Federalist Party-enacted Alien and Sedition Acts, however, placed all Federalist candidates in Virginia on the defensive. In an effort to defend their party from accusations of unconstitutional usurpation, the Federalist minority in the Virginia Assembly submitted

187 See Act of July 14, 1798, ch. 74, 1 Stat. 596, 596-97; Act of July 6, 1798, ch. 66, 1 Stat. 577, 577-78; Act of June 25, 1798, ch. 58, 1 Stat. 570, 570-71; Act of Jan. 29, 1795 , ch. 20, 1 Stat. 414, 414-15.

188 See Act of June 25, 1798, ch. 58, 1 Stat. at 570-71.

189 See Act of July 14, ch. 74, 1 Stat. at 596-97.

190 See James Madison, Virginia Resolutions (Dec. 21, 1798), in 5 The Founders' Constitution 135, 135-36 (Philip B. Kurland \& Ralph Lerner eds., 1987); see also Thomas Jefferson, Kentucky Resolutions (Nov. 10, 1798), in 5 THE Founders' ConsTITUTION, supra, at 131, 131-34.

191 See Kurt T. Lash \& Alicia Harrison, Minority Report: John Marshall and the Defense of the Alien and Sedition Acts, 68 Oноо St. L.J. 435, 494 (2007).

192 Id. at 449. 
its Report of the Minority on the Virginia Resolutions ("Minority Report") a defense of the Alien and Sedition Acts. ${ }^{193}$

The Minority Report, whose authorship at the time was unknown, presented a strong constitutional defense of the Acts and, in so doing, articulated an expansive vision of federal power. In response to claims that the Acts exceeded the implied necessary and proper powers of Congress, the author of the Minority Report argued that the omission of the term "expressly" from the text of the Tenth Amendment implied otherwise broad congressional authority:

The government of the United States is indubitably limited as to its objects, however it may be as to the means of obtaining those objects .... It is necessary in pursuing this inquiry to bear in mind that we are investigating a constitution which must unavoidably be restricted in various points, to general expressions, making the great outlines of a subject; and not a law which is capable of descending to every minute detail. . . .

... It would be difficult too, to assign a reason for omitting in the [Tenth] amendment to our constitution, which is evidently copied from the second article of the ancient confederation, the very material word expressly. That article of the confederation, and the amendment to our constitution, were designed as a plain and explicit admission of the principle, that the powers not delegated are retained. In the confederation all powers not expressly delegated are retained; but in the amendment, this very operative word is wisely omitted. ${ }^{194}$

This passage bears a number of striking similarities to arguments John Marshall would use decades later in McCulloch. Like the author of the Minority Report, Marshall would stress that "we must never forget, that it is a constitution we are expounding," 195 and that one should therefore expect broad pronouncements of general power rather than the "prolixity of a legal code."196 Marshall's argument in $\mathrm{McCul}$ loch also uses the exact same argument as the Minority Report in regard to the implications of the missing word "expressly."197 It should come as no surprise, therefore, to learn that the anonymous

193 See Report of the Minority on the Virginia Resolutions (Jan. 22, 1799), in 5 THE Founders' Constitution, supra note 190, at 136.

194 Address, Phila. Gazetre, Feb. 9, 1799, at l. In the bracketed text, the author referred to the "12th" proposed amendment to the Constitution, reflecting an early convention by which the original amendments were referred to according to the place on an original list of twelve proposed amendments. Our Tenth was the twelfth on that original list. See supra note 163

195 McCulloch v. Maryland, 17 U.S. (4 Wheat.) 316, 407 (1819).

196 Id

197 Id. at 406. 
authorship of the Minority Report has traditionally been attributed to none other than John Marshall himself. ${ }^{198}$

Although the Virginia and Kentucky Resolutions did not receive the support from other states wished for by Jefferson and Madison, Republicans continued to press their case against the Alien and Sedition Acts. James Madison drafted what would come to be known as "Madison's Celebrated Report of 1800" which provided a detailed analysis and defense of the Virginia Resolutions' claim that Congress had exceeded its powers and violated the Tenth Amendment. ${ }^{199}$ In his 1799 campaign pamphlet, future Governor John Page argued that the Alien and Sedition Acts were "not only unnecessary, impolitic and unjust, but unconstitutional."200 According to Page, the Acts violated the retained rights of the states as protected by the Ninth and Tenth Amendments. ${ }^{201}$ Specifically addressing the Virginia Minority Report's claims about implied federal power and the Tenth Amendment, Page insisted that the combination of the Ninth and Tenth

198 See, e.g., Richard R. Beeman, The Old Dominion and the New Nation 196 (1972); 2 Beveridge, supra note 5, at 402; Morton Frisch \& Richard Stevens, Political Thought of american Statesmen 75-76 (1973); Ralph Ketcham, James Madison 397 (1971); Letter from John Quincy Adams to William Vans Murray (Apr. 9, 1799), in 2 Writings of John Quincy Adams 402, 403 (Worthington C. Ford ed., 1913); Letter from Theodore Sedgwick to Alexander Hamilton (Feb. 7, 1799), in 22 The Papers of Alexander Hamilton 469, 470 (Harold C. Syrett et al. eds., 1975); John P. Roghe, John Marshall 32-34 (John P. Roche \& Stanley B. Bernstein eds., 1967); James Morton Smith, Freedom's Fetters 151 (1956); Jack L. Cross, John Marshall on the French Revolution and on American Politics, 12 WM. \& MARY Q. 631, 637 (1955); Morton J. Frisch, John Marshall's Philosophy of Constitutional Republicanism, 20 Rev. Pol. 34, 39 \& n.32 (1958); William E. Nelson, The Eighteenth-Century Background of John Marshall's Constitutional Jurisprudence, 76 MICH. L. Rev. 893, 933 (1978); Robert C. Palmer, The Federal Common Law of Crime, 4 Law \& Hist. Rev. 267, 277 (1986). Recent biographers of John Marshall have challenged this attribution. For a full discussionand rejection-of the attempts to erase Marshall's name from the Minority Report, see Lash \& Harrison, supra note 191.

199 See James Madison, Report on the Alien and Sedition Acts (Jan. 7, 1800), in James MAdison: Writings, supra note 116, at 608. For a discussion of the Report and its significance for later states' rights theory, see Kurt T. Lash, James Madison's Celebrated Report of 1800: The Transformation of the Tenth Amendment, 74 GEO. WASH. L. REV. $165,182-87$ (2006).

200 PAGE, supra note 13, at 9. Page was a member of Congress from 1789 to 1797, and Governor of Virginia from 1802 to 1805 . 4 Herringshaw's National Library of AMERICAN BIOGRAPHY 361 (Thomas William Herringshaw ed., 1914). Thus, not only was he in Congress when Madison gave his bank speech, he was a representative from Virginia at the time that state was considering the Bill of Rights. He would have been well aware of Madison's opposition to the Bank-indeed, the men regularly corresponded.

201 See PAGE, supra note 13, at 13-14. 
Amendments (which he referred to as the "11th and 12th") had restored the missing term from Article II of the Articles of Confederation. Below, I have provided an extended portion of his argument, as it presents a detailed and sophisticated analysis of the relationship between retained sovereignty and strict construction of delegated power:

For how could it be supposed when the $2 d$ article of the confederation declared that "each state retains its sovereignty, freedom, and independence, and every power, jurisdiction, and right, which is not by this Confederation expressly delegated to the U. States, in Congress assembled," and the design of appointing a convention and the authority given by the different confederated states to that convention went no farther than "to render the then Federal Constitution adequate to the exigencies of government and the preservation of the union," (neither of which could require farther powers in government than are expressly granted) that although the convention omitted the insertion of a familiar article; where as unnecessary in their opinion or, through design; (such as seems now avowed) as the amendment was made, and as these words preceded it in the 11th article, "the enumeration in the Constitution of certain rights shall not be construed to deny or disparage others retained by the people."

I say, considering these things, how could it be possible to suppose, that these two amendments taken together, were not sufficient to justify every citizen in saying, that the powers not delegated to the United States by the constitution, nor prohibited by it to the states, are reserved to the states respectively, or to the people, as fully and completely; as if the word expressly had been inserted? . . . And candour, and a respect for the majority the of congress which recommended the amendments ought to induce us to think, that they also were of the same opinion [that the $2 \mathrm{~d}$ art. of the art's still operated] and therefore that they would not have recommended the addition of the 11th and 12th articles to the constitution, had they not been called upon by some states for such amendments ...."202

Page was a member of the Congress that helped frame and submit the Bill of Rights, including the Ninth and Tenth Amendments. He was a member of the House when Madison gave his speech on the Bank of the United States and he represents yet another Virginian who believed that the Ninth and Tenth Amendments established that Congress would have none but expressly delegated powers. ${ }^{203}$

202 Id. at 28-29.

203 Other campaign documents distributed in the months leading up to the national election stressed the same reading of federal power. In an essay entitled $O n$ the Election of the President of the United States, the author declared: "[The Constitution] 
The same "popular sovereigntist" reading of the Ninth and Tenth Amendments can be found in court proceedings of the time, ${ }^{204}$ including an opinion by a member of the second North Carolina ratifying convention, ${ }^{205}$ John Overton. Overton went on to join the Tennessee bench and there presided over a case that contains one of the earliest state judicial references to the Ninth and Tenth Amendments. ${ }^{206}$ The background issue involved whether a state property judgment was binding on a portion of land falling within Indian territory. ${ }^{207}$ Overton held that it was, in part on the basis of retained sovereignty of the states:

But how far has the Constitution and laws of the United States, made in pursuance of it, abridged the sovereign rights of each State? The answer is easy. No further than the States have expressly, and not by equitable construction, delegated authority to the United States. The Constitution of the United States was proposed to each State possessing the rights of sovereignty within their respective limits. It proposed that each State should give up a portion of its sovereignty for the more secure and convenient enjoyment of the remainder. ${ }^{208}$

The elections of 1800 represented a triumph of the Republican vision of federal power. Federalists lost control of both political branches of the national government and the Alien and Sedition Acts were allowed to ignominiously expire (Jefferson pardoned those con-

appears to be founded entirely on the principle, that the federal government is only to exercise the powers that have been expressly delegated to it." A Republican, On the Election of the President of the United States, Carolina GazeTte (Charleston, S.C.), Sept. 4,1800 , at 1 .

204 See The Trial of Cyrus B. Dean 47 (Burlington, Samuel Mills 1808) ("We learn from the eleventh and twelfth articles of the first amendment to the Constitution of the United States that the enumeration in the constitution of certain rights, shall not be construed to deny or disparage others retained by the people; that the powers not delegated to the United States by the Constitution, nor prohibited by it to the States, are reserved to the States respectively. If then, Congress have power to intermeddle with the soil within a state's jurisdiction-to say who should, or rather who should not hold or possess it, this power must have been expressly delegated to the government of the United States.").

205 Although the first convention neither accepted nor rejected the Constitution, the second convention in 1789 voted in favor of ratification. See Chronology, 1786-1790, supra note 61 , at xl, xlii.

206 See Glasgow's Lessee v. Smith, 1 Tenn. (1 Overt.) 144, 149 (1805).

207 See id. at 144-45.

208 Id. at 166 (emphasis added) (footnote omitted). 
victed under the Sedition Act). ${ }^{209}$ For decades, the so-called Revolution of 1800 was viewed as a referendum on the proper interpretation of federal power. ${ }^{210}$ Having strongly criticized the constitutional theories underlying the Alien and Sedition Acts, ${ }^{211}$ St. George Tucker capitalized on the Republicans' victory and published the first treatise on the United States Constitution. In his View of the Constitution, Tucker summarized the rule of strict construction insisted upon by so many opponents of the hated Acts. According to Tucker:

The sum of [the Ninth and Tenth Amendments] appears to be, that the powers delegated to the federal government, are, in all cases, to receive the most strict construction that the instrument will bear, where the rights of a state or of the people, either collectively, or individually, may be drawn in question. ${ }^{212}$

\section{The Nationalism of John Marshall}

As the clock ran out on the outgoing Federalist administration, Adams nominated his Secretary of State, John Marshall, to the take the seat of the Chief Justice of the Supreme Court. By doing so, he insured that the same vision of federal power that animated the Alien and Sedition Acts would live to fight another day. A rise in national sentiment following the War of 1812,213 and an expanding country together created opportunities and incentives to expand the role of the federal government, particularly in the areas of finance ${ }^{214}$ and internal improvements. ${ }^{215}$ Doing so, however, required a more nationalist vision of federal power than that which had been promised

209 For a general account of the Acts and their aftermath, see David P. Currie, The Constitution in Congress: The Federalist Period 1789-1801, at 253-73 (1997).

210 For decades, the triumph of the Republicans was viewed as a vindication of the original understanding of the Constitution. See, e.g., Padelford, Fay \& Co. v. Mayor of Savannah, 14 Ga. 438, 494-95 (1854) (discussing the battle over the Alien and Sedition Acts as a battle for a rule of strict construction of the Constitution). In this way, the election of 1800 represents an example of the sovereign people acting "people out-of-doors" in order to defend their understanding of the Constitution. See Kramer, supra note 28, at 35, 45. For a general account of the struggle over the Alien and Sedition Acts and the influential election of 1800, see Lash, supra note 199, at 180-95.

211 See Tucker, supra note 69, app. at 356-61.

212 Id. at 154.

213 See WHITE, supra note 1 , at 87.

214 The War of 1812 created pressure on the nation's finances that "strengthened the case for a federal banking system." Jean Edward SMith, John Marshall 441 (1996).

215 See James Madison, Veto Message to Congress (Mar. 3, 1817), in James MAdison: Writings, supra note 116 , at $718,718-20$. 
to the states and had triumphed in the Revolution of $1800 . .^{216}$ That vision was supplied by Chief Justice John Marshall in McCulloch.

A trilogy of important cases came before the United States Supreme Court in the 1819 Term, including Sturges $v$. Crowninshield, ${ }^{217}$ Trustees of Dartmouth College v. Woodward, ${ }^{218}$ and McCulloch. Of the three, McCulloch was the last to be decided and, according to Marshall's first great biographer, Albert Beveridge, had Marshall's "fame rested solely on this one effort, it would be secure." 119 That general sentiment remains true today as $M c$ Culloch is broadly considered the seminal discussion of congressional power under the Constitution. ${ }^{220}$ Written soon after President Madison's veto of the bank bill on the grounds that the strict construction of the Constitution denied Congress such power, Marshall and the rest of the Court were determined to use $\mathrm{McCulloch}$ as an opportunity to establish a broad (or, in Marshall's words, "fair") reading of federal power. ${ }^{221}$

\section{Popular Sovereignty and McCulloch}

Prior to $M c$ Culloch, the most influential discussion of enumerated federal power was contained in St. George Tucker's View of the Constitution. Tucker's rule of strict construction was premised on the idea, borrowed from international law, that delegations of power from a sovereign ought to be strictly construed in order to retain all power not expressly delegated away. ${ }^{222}$ As the people of the states were the sovereigns who delegated power to the new federal government, "every power which has been carved out of the states ... is in like manner to be construed strictly, whenever a different construction might derogate from the rights and powers, which by [the Tenth Amendment]; are expressly acknowledged to be reserved to them

\footnotetext{
216 See id.

21717 U.S. (4 Wheat.) 122 (1819).

21817 U.S. (4 Wheat.) 518 (1819).

2194 BeVERIDGE, supra note 5, at 282.

220 A quick glance at the table of contents in constitutional textbooks and treatises will quickly confirm this. See, e.g., Kathleen M. Sullivan \& Gerald Gunther, Constitutional LAW, at xi, 63 (Robert C. Clark et al. eds., 16th ed. 2007).

221 Not long after McCulloch was decided, Justice Johnson wrote President Monroe on behalf of himself and the other Supreme Court Justices and informed him that "the lucid and conclusive reasoning" contained in $\mathrm{McCulloch}$ "completely commits them on the subject of internal improvements." Letter from Justice William Johnson to James Monroe (n.d.), in SмrTH, supra note 214, at 468, 468-69. Justice Johnson suggested that the opinion in McCulloch should be "printed and dispersed through the Union." Id. at 665 n.128.
}

222 See Tucker, supra note 69, app. at 142-43. 
respectively." ${ }^{23}$ Tucker, like Madison, believed that this rule was made express in the adoption of the Ninth and Tenth Amendments. ${ }^{224}$

John Marshall, however, rejected strict construction. In cases like McCulloch and Gibbons, he articulated a vision of federal power not only expansive for its day, but expansive enough to become the foundational theory of the modern administrative state. ${ }^{225}$ In 1819 , however, establishing such a vision required transplanting the locus of delegated sovereignty from Tucker's "people of the several states" to the undifferentiated people of the nation as a whole. In Marshall's very first paragraph on substantive principles of law, he attempted to do just that:

In discussing this question, the counsel for the State of Maryland have deemed it of some importance, in the construction of the constitution, to consider that instrument not as emanating from the people, but as the act of sovereign and independent States. The powers of the general government, it has been said, are delegated by the States, who alone are truly sovereign; and must be exercised in subordination to the States, who alone possess supreme dominion.

It would be difficult to sustain this proposition. The Convention which framed the constitution was indeed elected by the State legislatures. But the instrument, when it came from their hands, was a mere proposal, without obligation, or pretensions to it. . . . $[\mathrm{T}]$ he instrument was submitted to the people. They acted upon it in the only manner in which they can act safely, effectively, and wisely, on such a subject, by assembling in Convention. It is true, they assembled in their several states-and where else should they have assembled? No political dreamer was ever wild enough to think of breaking down the lines which separate the States, and of compounding the American people into one common mass. Of consequence, when they act, they act in their States. But the measures they adopt do not, on that account, cease to be the measures of the people themselves, or become the measures of the State governments. ${ }^{226}$

\section{Id. at 308.}

224 Id. at 143.

225 See Wickard v. Filburn, 317 U.S. 111, 120 (1942); United States v. Darby, 312 U.S. 100, 124 (1941). For a discussion of the New Deal Court's reliance on Marshall in construing federal power, see 1 ACKERMAN, supra note 28, at 62; see also Kurt T. Lash, The Constitutional Convention of 1937: The Original Meaning of the New Jurisprudential Deal, 70 Fordham L. Rev. 459, 487-89 (2001) (discussing New Deal Court decisions involving the scope of the commerce power).

226 McCulloch v. Maryland, 17 U.S. (4 Wheat.) 316, 402-03 (1819) (emphasis added). 
By characterizing Maryland as defending the sovereignty of the state governments, Marshall was able to present his view of federal power as resting on the sovereignty of the people. Maryland, however, had made no such argument. Walter Jones, ${ }^{227}$ for example, had insisted on behalf of Maryland

that the Constitution was formed and adopted, not by the people of the United States at large, but by the people of the respective States. ... It is, therefore, a compact between the States, and all the powers which are not expressly relinquished by it, are reserved to the States. 228

By mischaracterizing Maryland's argument as advocating complete state sovereignty, Marshall was able to avoid the critical question of how best to construe powers delegated by the sovereign people of the states. Limiting his discussion to the people as a national body, Marshall declared that it was of no relevance that the people ratified the Constitution in their respective states-"where else should they have assembled?"229

Over and over again in his opinion, Marshall presents the issue as one involving a contest between "sovereign states" and a "sovereign people," the latter being a reference to a national people. "The government of the Union," Marshall declared, "is, emphatically, and truly, a government of the people. In form and in substance it emanates from them. Its powers are granted by them, and are to be exercised directly on them, and for their benefit."230 As far as the Tenth

227 According to Mark Killenbeck, "Jones was the least prominent of the six men who argued but had a reputation as a 'legal genius.' " KILlenbeck, supra note 1, at 102.

228 McCulloch, 17 U.S. (4 Wheat.) at 363.

229 Id. at 403.

$230 I d$. at $404-05$. Here Marshall builds upon arguments originally presented by his fellow Justice, Joseph Story, in Martin v. Hunter's Lessee, 14 U.S. (1 Wheat.) 304 (1816). There, Story argued:

These deductions do not rest upon general reasoning, plain and obvious as they seem to be. They have been positively recognised by one of the articles in amendment of the constitution, which declares, that "the powers not delegated to the United States by the constitution, nor prohibited by it to the states, are reserved to the states respectively, or to the people."

The government, then, of the United States, can claim no powers which are not granted to it by the constitution, and the powers actually granted, must be such as are expressly given, or given by necessary implication. On the other hand, this instrument, like every other grant, is to have a reasonable construction, according to the import of its terms; and where a power is expressly given in general terms, it is not to be restrained to particular cases, unless that construction grow out of the context expressly, or by necessary 
Amendment was concerned, this clause was as irrelevant as the fact of state-by-state ratification. The clause was not adopted to control the interpretation of federal power, but "was framed for the purpose of quieting excessive jealousies which had been excited."231 The fact that the Framers omitted the restrictive term "expressly" indicated their desire that Congress have "incidental or implied powers" as well as those expressly enumerated. ${ }^{232}$ Rather than strict construction, proper interpretation of federal power "depend[ed] on a fair construction of the whole instrument."233 And Marshall's idea of a fair construction was broad indeed: "[W] here the law is not prohibited, and is really calculated to effect any of the objects entrusted to the government, to undertake here to inquire into the degree of its necessity, would be to pass the line which circumscribes the judicial department, and to tread on legislative ground."234

Marshall's construction of federal power has been embraced so widely and for so long that it takes some effort to appreciate the radical nature of his argument. So long as a law is "calculated to effect" any of the objects entrusted to the government ${ }^{235}$ (not actually effects), Congress could employ any means so long as they were not "prohibited" by the Constitution-regardless of the degree of necessity. In his second great opinion on national power, Gibbons, Marshall wrote that congressional power to regulate commerce was "complete in itself, may be exercised to its utmost extent, and acknowledges no limitations, other than are prescribed in the constitution."236 Whatever one makes of the Ninth and Tenth Amendments, at a minimum they were designed to prevent just this kind of argument-that the only limits to federal power were those listed in the Constitution. Marshall, however, rejected the idea that any clause in the Constitution suggested any limit to federal power beyond those expressly listed in the text:

implication. The words are to be taken in their natural and obvious sense, and not in a sense unreasonably restricted or enlarged.

$I d$. at 325-26. Notice that Story reads the Tenth Amendment as recognizing an undifferentiated national people. In this passage Story also manages to move from the federal government having no powers but those "expressly given, or given by necessary implication," to powers broadly construed unless a strict construction is expressly required or arises "by necessary implication." Id. at 326.

231 McCulloch, 17 U.S. (4 Wheat.) at 406.

232 See id.

233 Id. (emphasis added).

234 Id. at 423.

235 See id.

236 Gibbons v. Ogden, 22 U.S. (9 Wheat.) 1, 196 (1824). 
This instrument contains an enumeration of powers expressly granted by the people to their government. It has been said, that these powers ought to be construed strictly. But why ought they to be so construed? Is there one sentence in the constitution which gives countenance to this rule? In the last of the enumerated powers, that which grants, expressly, the means for carrying all others into execution, Congress is authorized "to make all laws which shall be necessary and proper" for the purpose. But this limitation on the means which may be used, is not extended to the powers which are conferred; nor is there one sentence in the constitution, which has been pointed out by the gentlemen of the bar, or which we have been able to discern, that prescribes this rule. We do not, therefore, think ourselves justified in adopting it. ${ }^{237}$

When one combines McCulloch and Gibbons, it appears that Marshall had effectively flipped the Ninth and Tenth Amendments on their heads: a government broadly conceived to have no more than expressly enumerated powers had been transformed into a government with only expressly enumerated restrictions. Marshall's nationalist vision of the Constitution derived much of its rhetorical persuasiveness by comparing his broad view of federal power with what he portrayed as the impossibly restrictive view of strict constructionists. Maryland, according to Marshall, claimed that only the states "are truly sovereign" and that federal power "must be exercised in subordination to the States, who alone possess supreme dominion."238 Once again, Maryland had argued no such thing, but saying so made Marshall's opinion seem all the more reasonable. It allowed Marshall to take the rhetorical high ground of popular sovereignty, where the people were conceived as a single sovereign national people and whose implied powers had no limit beyond those listed in the Constitution.

In his opening section in McCulloch, Marshall implied that Madison and other original opponents of the Bank had changed their minds about the constitutionality of the Bank and had come to share a broader view of federal power. ${ }^{239}$ Madison, however, had never changed his opinion that the Constitution, properly construed, did not grant Congress the power to charter the Bank. In his Detached Memoranda, Madison criticized Marshall for "[i]mputing the concur-

\section{Id. at $187-88$.}

238 McCulloch, 17 U.S. (4 Wheat.) at 402.

239 See id. ("The original act was permitted to expire; but a short experience of the embarrassments to which the refusal to revive it exposed the government, convinced those who were most prejudiced against the measure of its necessity, and induced the passage of the present law."). 
rence of those formerly opposed to change of opinion, instead of precedents superseding opinion."240 Madison rejected Marshall's arguments in $\mathrm{McCulloch}$ and wrote that the decision was based on "erroneous views." Top on Madison's list of Marshall's "errors" was the Chief Justice's assertion about "the people" ratifying the Constitution, "if [by this he] meant people collectively \& not by States."241 This fundamental error had led to Marshall "[e]xpounding power of Cong[ress] - as if no other Sovereignty existed in the States supplemental to the enumerated powers of Cong[ress]."242

In fact, it was Marshall's assertion of undifferentiated national sovereignty that triggered an immediate public outcry following the publication of McCulloch. In the broadsides that followed, it was not so much the Bank that critics deplored as Marshall's vision of sovereignty. McCulloch was excoriated in Republican newspapers as embracing the same nationalist theories that had led to the adoption (and defense) of the hated Alien and Sedition Acts. When one compares the language and reasoning of McCulloch with that of the Minority Report, the criticisms seem justified.

\section{After Marshall}

Marshall's expansive vision of federal power did not survive his tenure on the Supreme Court. Even before his death, the Court began to back away from his most expansive readings of federal power. ${ }^{243}$ Within a few years of his death, the Court had embarked on what would become the dominant jurisprudence of the nineteenth

240 James Madison, Detached Memoranda (n.d.), in JAmes Madison: Writings, supra note 116, at 745, 756. Despite his objections to the First Bank of the United States, then-President Madison signed into law the bill for the Second Bank of the United States. See Act of Apr. 10, 1816, ch. 44, 3 Stat. 266. Doing so opened him to criticism as having acted inconsistently with his stated view on the constitutionality of the First Bank. Madison insisted, however, that he had not changed his mind, but nevertheless believed that acquiescence was appropriate as a matter of precedent, particularly in light of the acceptance of the Bank by numerous political majorities. See Madison, supra. For a discussion of Madison's view of precedent and proper constitutional interpretation, see Lash, supra note 25, at 1448.

241 Madison, supra note 240 , at 756.

242 Id.

243 In cases like Ogden v. Saunders, 25 U.S. (12 Wheat.) 213 (1827), Willson v. Black Bird Creek Marsh Co., 27 U.S. (2 Pet.) 245 (1829), Providence Bank v. Billings, 29 U.S. (4 Pet.) 514 (1830), Hawkins v. Barney's Lessee, 30 U.S. (5 Pet.) 457 (1831), and Barron v. Mayor of Baltimore, 32 U.S. (7 Pet.) 243 (1833), the Supreme Court opted for either a narrow view of federal power or a broad view of state authority. 
century-narrow construction of federal power. ${ }^{244}$ Sensing the need to shore up the theoretical justifications for his mentor's nationalist vision of federal power, Joseph Story dedicated his Commentaries on the Constitution to the Chief Justice and proceeded to attack compact theories of the Constitution presented in works like Tucker's View of the Constitution. ${ }^{245}$ Story was particularly disparaging of those who would replace Marshall's vision with a strict reading of federal power:

When this amendment was before Congress, a proposition was moved, to insert the word "expressly" before "delegated," so as to read "the powers not expressly delegated to the United States by the Constitution." On that occasion it was remarked, that it is impossible to confine a government to the exercise of express powers. . . .

It is plain, therefore, that it could not have been the intention of the framers of this amendment to give it effect, as an abridgment of any of the powers granted under the Constitution, whether they are express or implied, direct or incidental. ... The attempts then which have been made from time to time to force upon this language an abridging or restrictive influence are utterly unfounded in any just rules of interpreting the words or the sense of the instrument. Stripped of the ingenious disguises in which they are clothed, they are neither more nor less than attempts to foist into the text the word "expressly;" to qualify what is general, and obscure what is clear and defined. ${ }^{246}$

Notice that Story reads the omission of the term "expressly" as opening the door not only to implied powers but, more crucially, to "incidental" (indirect) powers. This extends federal powers beyond those closely associated with expressly defined powers (those directly involved) and embraces any implied means "incidentally" related to those powers. Story thus reads the omission of the term expressly as requiring the rejection of both the broad and narrow meanings of "expressly delegated powers." Indeed, according to Story, the Tenth Amendment had no "restrictive" influence whatsoever. Not surpris-

244 See Mayor of N.Y. v. Miln, 36 U.S. (11 Pet.) 102, 139 (1837) (narrowly construing the Commerce Clause and declaring "all those powers which relate to merely municipal legislation, or what may, perhaps, more properly be called internal police, are not thus surrendered or restrained; and that, consequently, in relation to these, the authority of a state is complete, unqualified, and exclusive"); see also Hammer v. Dagenhart, 247 U.S. 251, 276-77 (1918) (striking down a federal law regulating the transportation of goods moving in interstate commerce); The Civil Rights Cases, 109 U.S. 3, 24-26 (1883) (striking down federal power to prohibit private discrimination in public accommodations); The License Cases, 46 U.S. (5 How.) 504, 586 (1847) (sustaining state law against a claim of exclusive federal power over liquor licenses). 245 See R. Kent Newmyer, Supreme Court Justice Joseph Story 180-93 (1985).

2462 STORY, supra note 4 , $\$$ 1907-1908, at 652-53. 
ingly, Story supported both Marshall's interpretation of the Tenth Amendment in $\mathrm{McCulloch} \mathrm{C}^{247}$ and Marshall's expansive reading of federal power in Gibbons. ${ }^{248}$

As Marshall had recognized in McCulloch, Story knew that the key to establishing a broad vision of federal power lay in locating sovereignty in a national people, and not in the people of the several states. ${ }^{249}$ Marshall had argued that although the people may have delegated sovereign power to the states prior to the Constitution, they had "resumed" all such power and then, acting as a national people, delegated it anew to the federal government with the ratification of the Constitution. ${ }^{250}$ Story went even further and argued that there had never been any sovereign and independent states, but that sovereignty had descended on the national people at the moment they declared their independence in 1776-a view even Story's biographer calls "as metaphysical as the states' rights school he criticized."251

But Story was fighting a losing battle. Even before he and Marshall retired, the Court had begun to back away from Marshall's nationalist vision of federal power. Cases such as Willson v. Black Bird Creek Marsh Co.,${ }^{252}$ and especially Mayor of New York v. Miln, ${ }^{253}$ rejected the idea of exclusive federal power over local matters affecting interstate commerce (hinted at in Gibbons), and instead flipped the idea on its head by holding that it was the states that had exclusive authority over certain municipal matters-regardless of their impact on interstate commerce. ${ }^{254}$ Witnessing the end of Marshall's nationalist con-

$247 \quad 1$ id. $\$ \S 1048-1053$, at $759-62$.

2482 id. $\$ \S 1067-1073$, at $12-23$.

249 As Story biographer R. Kent Newmyer writes, "The definition and location of sovereignty in the American federal system was, as Story correctly perceived, the foundation on which all else rested." See Newmyer, supra note 245, at 184 (discussing how the Commentaries "made sovereignty unequivocally descend on the American people in $1776 ")$.

250 See McCulloch v. Maryland, 17 U.S. (4 Wheat.) 316, 404 (1819) ("It has been said, that the people had already surrendered all their powers to the State sovereignties, and had nothing more to give. But, surely, the question whether they may resume and modify the powers granted to government, does not remain to be settled in this country.").

251 NeWMYER, supra note 245, at 184.

25227 U.S. (2 Pet.) 245 (1829).

25336 U.S. (11 Pet.) 102 (1837).

254 According to Justice Barbour in Miln:

A state has the same undeniable and unlimited jurisdiction over all persons and things, within its territorial limits, as any foreign nation; where that jurisdiction is not surrendered or restrained by the constitution of the United States. . . That all those powers which relate to merely municipal legislation, or what may, perhaps, more properly be called internal police, are not 
struction of the Constitution, Justice Story could only pen dissents ${ }^{255}$ and lament in his letters: "I am the last of the old race of Judges. I stand their solitary representative, with a pained heart, and a subdued confidence. Do you remember the story of the last diner of a club, who dined once a year? I am in the predicament of the last survivor."256

Despite their best efforts, John Marshall and Joseph Story failed to exorcise either the term or the principle of "expressly" delegated power. In his polemic against the Court's decision in $\mathrm{McCulloch}$, John Taylor declared the principles that would ultimately dominate judicial construction of federal power from Marshall's retirement until the time of the New Deal. According to Taylor, the Federal Constitution "excludes congress from exercising internal powers over persons and property, not expressly delegated." 257 The textual source of this principle could be found in the Ninth and Tenth Amendments:

The [Ninth] amendment prohibits a construction by which the rights retained by the people shall be denied or disparaged; and the [Tenth] "reserves to the states respectively or to the people the powers not delegated to the United States, nor prohibited to the states." The precision of these expressions is happily contrived to defeat a construction, by which the origin of the union, or the sovereignty of the states, could be rendered at all doubtful. ${ }^{258}$

According to Thomas Law's antebellum work, The Statesman's Manual of the Constitution of the United States:

thus surrendered or restrained; and that, consequently, in relation to these, the authority of a state is complete, unqualified, and exclusive.

$I d$. at 139. For a discussion of the Taney Court's move away from the nationalist vision of John Marshall, see Kurt T. Lash, "Tucker's Rule": St. George Tucker and the Limited Construction of Federal Power, 47 WM. \& MARY L. Rev. 1343, 1382-85 (2006).

255 Dissenting in the Miln case, Story remonstrated:

I have the consolation to know that I had the entire concurrence, upon the same grounds, of that great constitutional jurist, the late Mr. Chief Justice Marshall. Having heard the former arguments, his deliberate opinion was, that the act of New York was unconstitutional; and that the present case fell directly within the principles established in the case of Gibbons v. Ogden ....

Miln, 36 U.S. (11 Pet.) at 161 (Story, J., dissenting).

256 Letter from Joseph Story to Harriet Martineau (Apr. 7, 1837), in 2 LiFE AND LetTers of Joseph Story 275, 277 (William W. Story ed., Boston, Little \& Brown 1851).

257 John Taylor, Construction Construed, and Constitutions Vindicated 298 (Richmond, Shepherd \& Pollard 1820).

258 Id. at 46. 
The Articles of Confederation also adopted the title "United States of America," at the same time declaring that "each State retains its sovereignty, freedom and independence, and every power and right which is not expressly delegated to the United States in Congress assembled." The Tenth Amendment of the present Constitution makes the same declaration. ${ }^{259}$

Finally, if only to illustrate the durability of the principle beyond the fall of the Confederacy and the radical states' rights theories of men like John C. Calhoun, here is the Supreme Court's articulation of the principle in 1869-a year after the adoption of the Fourteenth Amendment:

The people of the United States constitute one nation, under one government, and this government, within the scope of the powers with which it is invested, is supreme. On the other hand, the people of each State compose a State, having its own government, and endowed with all the functions essential to separate and independent existence. The States disunited might continue to exist. Without the States in union there could be no such political body as the United States.

Both the States and the United States existed before the Constitution. The people, through that instrument, established a more perfect union by substituting a national government, acting, with ample power, directly upon the citizens, instead of the Confederate government, which acted with powers, greatly restricted, only upon the States. But in many articles of the Constitution the necessary existence of the States, and, within their proper spheres, the independent authority of the States, is distinctly recognized. To them nearly the whole charge of interior regulation is committed or left; to them and to the people all powers not expressly delegated to the national government are reserved. The general condition was well stated by $\mathrm{Mr}$. Madison in the Federalist, thus: "The Federal and State governments are in fact but different agents and trustees of the people, constituted with different powers and designated for different purposes." 260

As Chief Justice Salmon Chase's opinion emphasizes, the principle of "expressly delegated power" is derived from the theory of popular sovereignty. The people, whether viewed as a single national collective or as the many peoples of the individual states, remain the source of all delegated authority. As a mere agent of the people, the government can claim no powers beyond those expressly delegated to it.

259 Thomas Law, The Statesman's Manual of The Constitution of the United States 11 (n.p., n.d.).

260 Lane County v. Oregon, 74 U.S. (7 Wall.) 71, 76 (1869) (emphasis added). 


\section{James Madison's Middle Ground 261}

Much of the discussion in this Article might appear to recapitulate the well-known battles between those who viewed the Constitution as creating a national people and those who insisted on viewing the Constitution as no more than a compact between the states. This dualist approach is how the arguments in $\mathrm{McCulloch}$ are generally viewed with Marshall representing the (correct) view of a strong national government and Maryland representing the (unworkable) compact theory of the Constitution. In the years following the $\mathrm{McCul}$ loch decision, there did in fact develop a strong movement in favor of compact theory and the right of states to interpret the Constitution for themselves, resist the enforcement of disfavored federal law and, ultimately, to secede from the Union. Driven by a growing list of southern state grievances and a hardening determination to preserve (and extend) slavery at all costs, the Calhounians of the pre-Civil War era articulated a theory of the Constitution that James Madison rejected as utterly alien to the original understanding of the Founders. ${ }^{262}$

There was, however, a middle way between the extremes of wholly nationalist and wholly localist (Federalist) readings of the Constitution. Just as Madison rejected the theory of the nullifiers, he just as strongly rejected the nationalist reading of the Constitution pressed by Alexander Hamilton and (later) John Marshall. Articulating a view of the Constitution that he would hold for the rest of his life, Madison's famous Federalist No. 39 presents the Constitution as a compromise between nationalist and federalist theories of government:

The proposed Constitution, therefore ... is, in strictness, neither a national nor a federal Constitution, but a composition of both. In its foundation it is federal, not national; in the sources from which the ordinary powers of the government are drawn, it is partly federal and partly national; in the operation of these powers, it is national, not federal: In the extent of them, again, it is federal, not national; and, finally in the authoritative mode of introducing amendments, it is neither wholly federal nor wholly national. ${ }^{263}$

261 I owe this subpart's title to the fine work of Charles Lofgren. See Lofgren, supra note 30, at 336 (writing of James Madison's "Middle Ground" and its fate).

262 See Letter from James Madison to Edward Everett (Aug. 28, 1830), in JAMEs MADISON: WRITINGS, supra note 116 , at 842,842 (rejecting the doctrine of nullification); Letter from James Madison to Mathew Carey (July 27, 1831), in JAMEs MADISON: WRITINGS, supra note 116 , at $858,858-59$ (same).

263 The Federalist No. 39 (James Madison), supra note 34, at 246. 
Notice that Madison sees the foundation of the Constitution as federal-meaning that it required the consent of the people in the several states, and not a single national plebiscite, to bring the Constitution into being. This is a critical move in that it makes the powers of the national government a delegation from sovereign states. However, even if the Constitution was brought into being by the people in the several states, it necessarily created a national people at the same time it preserved the independent existence of the states. Thus, future amendments would involve a mechanism both national and federal. Unlike the original ratification, dissenting states could be bound by future amendments, but those amendments would be ratified on a state-by-state basis, and not through a single national vote. ${ }^{264}$

The political theory driving this "mixed" view of the Constitution was not one of divided sovereignty (the dreaded imperium in imperio), but one of divided sovereign power. ${ }^{265}$ The people had exercised their sovereign right to delegate some degree of sovereign power to the national government while retaining a degree of sovereign authority to the independent states. States that joined the Union were obligated to obey legitimate exercises of federal power (expressly so under the Supremacy Clause). However, because the delegation of authority which created the federal government came out of the independent states, it was to be strictly construed-as required by the norms of international law and as promised by the advocates of the Constitution.

Madison's simultaneous struggle against the views of nullifiers and the views of the nationalists reflects his lifelong effort to balance these competing ideas of sovereign authority. When the national government exercised power over seditious speech, Madison opposed the effort on the grounds that it exceeded the properly interpreted express powers of the government, thus violating the Tenth Amendment. ${ }^{266}$ When the nullifiers of the 1820 s and ' 30 s attempted to use Madison's arguments against the Alien and Sedition Acts in support of their claim that states could unilaterally nullify federal law, Madison

264 See U.S. Const. art. V (requiring two-thirds of the states (or two-thirds of both houses of Congress) to propose an amendment and three-fourths of the states to ratify).

265 See Lofgren, supra note 30, at 341; see also MorGAN, supra note 76, at 267 ("To that end [Madison] envisioned a genuine national government, resting for its authority, not on the state governments and not even on the peoples of the several states considered separately, but on an American people, a people who constituted a separate and superior entity, capable of conveying to a national government an authority that would necessarily impinge on the authority of the state governments.").

266 See supra note 199 and accompanying text. 
opposed that effort as misreading his work and violating the Constitution's balance of federal and state authority. ${ }^{267}$ Over and over again, Madison found himself opposing the exaggerated claims of one side or the other in the neverending battle to balance state and federal authority.

Ultimately, of course, the center did not hold. A Civil War and the enactment of the Reconstruction Amendments significantly altered the original balance between state and federal authority. (Despite the states losing a significant degree of authority over matters originally viewed as "local," nothing in the Reconstruction Amendments altered the political nature of either the federal or state governments.) Federal power remained limited under the theory of delegated sovereignty ${ }^{268}$ and enumerated power, while the states remained constituent parts of the constitutional structure through their continued independent role in constitutional amendments. As long as the federal government remained an agent of the people, whether viewed in their national or state-level capacity, the proper rule of construction regarding delegated authority remained the same.

\section{Conclusion}

As Gordon Wood recounts in his magisterial Creation of the American Republic, the Federalists succeeded in their efforts to supplant the old Articles of Confederation with a new Constitution by stressing the ultimate sovereignty of the people. ${ }^{269}$ Although popular sovereignty was a new concept in American political theory, by 1787 it had nevertheless become the dominant understanding of the legitimate source of government authority. Vestiges of the older system remained, however, including the assumption that "all rights not expressly and unequivocally reserved to the people are impliedly and incidentally relinquished to rulers." 270 State governments, for example, were presumed to have general authority to act on the people's behalf absent an express restriction in the state constitutions' declarations of rights. It was due to this vision of "expressly retained rights" that the Antifederalists objected to the omission of a Bill of Rights in the proposed

267 See Letter from James Madison to Edward Everett, supra note 262, at 852 (claiming that the nullifiers were wrong to claim the Virginia Resolutions supported their cause).

268 See, e.g., Alden v. Maine, 527 U.S. 706, 758-59 (1999).

269 See Wood, supra note 52, at 536-43.

2703 Elliot's Debates, supra note 9, at 445 (reporting the statement of Patrick Henry on June 14, 1788). 
Constitution. ${ }^{271}$ In response, the Federalists flipped this vision completely around and, stressing the emergent theory of popular sovereignty, insisted that all powers and rights were retained to the people in the states other than those expressly delegated away. This was the vision of federal power presented to the state conventions, and, as James Madison insisted his entire life, this was the vision state conventions reasonably relied upon in ratifying the Federal Constitution.

This combination of Federalist explanation and ratifier reliance explains how a word could be omitted from the Tenth Amendment, but nevertheless embraced both before and after the adoption of the Bill of Rights. The concept of expressly delegated power and retained sovereignty was an accepted principle of the law of nations; sovereign power must be assumed retained absent an express delegation. Put another way, delegated power must be narrowly construed in favor of the grantor. Despite John Marshall's best efforts to portray the national government as having received delegated power from an undifferentiated people of the United States, the founding vision of independent peoples endured, as did the concept of strict construction of delegated sovereign power. It was not until the twentieth century that the rule of strict construction withered and Marshall's vision was revived to provide historical support for the rise of the modern regulatory state. ${ }^{272}$

Today, although the Tenth Amendment has seen its fortunes rise and fall over the past century, the text remains universally accepted as a statement of states' rights-even if the text is treated as expressing no more than a truism. ${ }^{273}$ This renders the Amendment's closing declaration of the ultimate sovereignty of the people as something of an oddity-either ignored altogether or construed in a manner completely the opposite of the same words in the Ninth Amendment. In the beginning, however, the words "by the people" and "to the people" represented the same concept of retained sovereignty, a concept which necessarily entails a strict construction of delegated power.

The original meaning of the Tenth Amendment thus sheds light on the original meaning of the Ninth. As dual expressions of popular sovereignty, the clauses mutually reinforced the idea of limited federal power. This is how Madison presented the clauses, and this is how the two Amendments were read for the first one hundred and fifty years

271 See Wood, supra note 52, at 541.

272 See Wickard v. Filburn, 317 U.S. 111 (1942); United States v. Darby, 312 U.S. 100 (1941); supra note 225 and accompanying text.

273 See, e.g., New York v. United States, 505 U.S. 144, 156 (1992). 
of the Constitution. ${ }^{274}$ Also, because the principle of expressly delegated power applied to all delegated powers, the attendant rule of strict construction would have applied to the interpretation of Article III and the jurisdiction of the federal courts. When the Supreme Court ruled in Chisholm v. Georgia ${ }^{275}$ that Article III allowed federal courts to hear suits brought by private individuals against the states, ${ }^{276}$ the immediate response by state legislatures was that the Court had engaged in an unduly broad reading of the text. The Eleventh Amendment's declaration that Article III shall not be construed to allow such suits in federal court ${ }^{277}$ echoes the same principle of strict construction that informed the Ninth and Tenth Amendments. This, along with the fact that the Amendment was proposed less than three years after the adoption of the Ninth and Tenth Amendments, suggests there may be far more commonality between these three amendments than has generally been recognized. ${ }^{278}$

Finally, if the reading of history in this Article is accurate, then it calls into question the traditional reading of John Marshall's opinion in $\mathrm{McCulloch}$ and its place in our understanding of the original meaning of federal power. Marshall's reading of the Tenth Amendment adopted a deeply contested understanding of "the people" and rejected the principle of expressly delegated power which had been promised by the proponents of the Constitution. Although Marshall correctly identified the original understanding that Congress would have implied powers, his rejection of a narrow interpretation of those implied powers conflicts with the historical record and the original understanding of retained sovereign power and rights.

In terms of modern doctrine, it appears that the Supreme Court's recent attempts to enforce federalist limits on congressional authority have greater textual and historical warrant than previously sup-

274 See Lash, Lost Jurisprudence, supra note 29, at 643 (observing that Madison and other writers of his generation regarded the Ninth and Tenth Amendments as "twin guardians of federalism"). As I have discussed elsewhere, although the clauses are mutually reinforcing and overlap to some degree, they nevertheless express distinct principles of limited federal power. See Lash, Textual-Historical Theory, supra note 29, at $919-21$.

2752 U.S. (2 Dall.) 419 (1793).

276 Id. at 473-78 (opinion of Jay, C.J.).

277 U.S. Const. amend. XI ("The Judicial power of the United States shall not be construed to extend to any suit in law or equity, commenced or prosecuted against one of the United States by Citizens of another State, or by Citizens or Subjects of any Foreign State.")

278 I plan to explore these connections in an upcoming article. 
posed. ${ }^{279}$ Obviously, the original scope of state autonomy was significantly curtailed by the adoption of later amendments, in particular the Fourteenth. ${ }^{280}$ However, assuming that the Ninth and Tenth Amendments were not fully repealed in 1868, there remains the important work of determining where national authority ends and the retained sovereign powers and rights of the people in the states begin. ${ }^{281}$ Indeed, the history presented in this Article suggests that the Supreme Court's enforcement of federalist separation of powers is as much an aspect of enforcing the Bill of Rights as is the Court's enforcement of individual rights. An adequate exploration of all these issues must be left to later works. The goal of this particular Article is to challenge the blithe assumption that the omission of a word requires the rejection of a principle.

279 See, e.g., United States v. Morrison, 529 U.S. 598 (2000); Printz v. United States, 521 U.S. 898 (1997); Lopez v. United States, 514 U.S. 549 (1995); New York v. United States, 505 U.S. 144 (1992). But see Gonzales v. Raich, 545 U.S. 1 (2005) (broadly interpreting the commerce power).

280 For a discussion of how the historical Ninth and Tenth Amendments might be reconciled with the Fourteenth Amendment, see Lash, supra note 145, at 875-79.

281 As is usually the case, James Madison provided us with a number of clues regarding how this principle of expressly delegated power might be put into practice. Madison believed that, over time, judicial review would produce specific doctrines and "legal landmarks" clarifying the area of retained sovereignty even as it allowed for the legitimate exercise of federal authority. We have some idea of what Madison viewed as proper landmarks. See supra note 215 (internal improvements veto); supra notes 162-163 (the bank speech). But Madison also left room for "political precedent" whereby an otherwise unduly broad exercise of federal power might receive sufficient sanction over time that later courts would be obliged to uphold the power as a matter of entrenched precedent. For an analysis of Madison's views on originalism and precedent, see Lash, supra note 25, at 1444-53. 